\title{
THE PERSONAL PROPERTY SECURITY ACT OF ALBERTA - IMPLICATIONS FOR OIL AND GAS LENDERS
}

\author{
$M$. JACQUELINE SHEPPARD and \\ LORAINE C. CHAMPION*
}

The proposed Personal Property Securing Act introduces a new statuon regime for taking and perfecting securin interests in personal property. Lawyers acting in secured transactions involving oil and gas assets must become knowledgeable about the Act and its advantages and pitfalls. The paper reviews key concepts introduced by the Act and assesses the impact of the Act on secured oil and gas financings.

TABLE OF CONTENTS

I. OVERVIEW OF THE PAPER AND THE PPSA
A. INTRODUCTION
B. OVERVIEW OF THE PAPER

C. ASSET BASE OF AN OIL AND GAS COMPANY

D. GENERAL SCHEME OF THE PPSA 36

II. SECURITY INTERESTS $\quad 38$

A. PRE-PPSA CATEGORIZATIONS 38

B. SECURITY INTEREST AS DEFINED IN THE PPSA 38

C. NON-SECURITY INTERESTS 39

D. INTANGIBLES - THE CATCH-ALL CATEGORY 39

E. SECURITY INTERESTS IN OIL AND GAS ASSETS 39

F. ILLUSTRATIONS OF SECURITY INTERESTS 40

G. EXCLUSIONS FROM THE PPSA 41

III. ATTACHMENT AND PERFECTION 43

$\begin{array}{ll}\text { A. GENERAL } & 43 \\ \end{array}$

B. ATTACHMENT 43

C. POSTPONED ATTACHMENT 44

D. ATTACHMENT AND AFTER-ACQUIRED PROPERTY 45

E. PERFECTION $\quad 45$

F. PERFECTION BY POSSESSION 46

G. PERFECTION BY REGISTRATION 48

H. ACTUAL NOTICE $\quad 49$

I. TEMPORARY PERFECTION 50

IV. PROCEEDS,CONTINUOUS PERFECTION AND
PROCESSED GOODS

A. THE GENERAL RULE $\quad 52$

B. APPLICATION TO HYDROCARBONS 52

C. PROCEEDS 55

D. PRIORITY RULES 56

E. SUMMARY 57

F. SECURITY INTERESTS IN PROCESSED OR
COMMINGLED GOODS

V. PRIORITIES OVERVIEW $\quad 58$

A. GENERAL RULES 58

* Blake, Cassels \& Graydon, Calgary, Albera. 
[VOL. XXIX, NO. 1

B. PURCHASE-MONEY SECURITY INTEREST

C. RISK FROM FAILURE TO PERFECT 60

VI. FLOATING CHARGES - THE GOOD NEWS AND THE BAD NEWS 61

A. THE GOOD NEWS

1. History and Nature of Floating Charges 61

2. Fixed Versus Floating Charge Security

3. The PPSA and Floating Charges

4. PPSA Case Law and Floating Charges 64

5. Conclusion

B. THE BAD NEWS - FLOATING CHARGES OVER
REAL PROPERTY

VII. FIXTURES AND ACCESSIONS 67

A. FIXTURES 67

B. OIL AND GAS ASSETS 69

C. THE PPSA AND FIXTURES

D. CONCLUSION 73

E. ACCESSIONS 73

VIII. INTERACTION BETWEEN THE PPSA AND

A. BANK ACT SECURITY 74

B. REGISTRATION UNDER THE PPSA

C. PRIORITIES ISSUES

1. Conflict between the Bank Act and the PPSA 78

2. Consecutive Security $\quad 80$

3. Contemporaneous Security 80

IX. NOTICE TO ACCOUNT DEBTORS REQUIRED UNDER THE PPSA 81

A. GENERAL AND SPECIFIC ASSIGNMENTS OF REVENUES 81

B. SHOULD ACCOUNT DEBTORS BE NOTIFIED OF GENERAL OR SPECIFIC ASSIGNMENTS AFTER THE

PPSA BECOMES EFFECTIVE?

C. SPECIAL PROVISIONS OF THE PPSA DEALING

WITH ACCOUNT RECEIVABLES

\section{OVERVIEW OF THE PAPER AND THE PPSA}

\section{A. INTRODUCTION}

On October 1, 1990, the Personal Property Security Act" (the "PPSA" or the "Act") is scheduled to become law, thereby bringing Alberta into the era of modern personal property security law. Ontario, Manitoba, Saskatchewan and the Yukon Territory all have similar personal property security legislation, ${ }^{2}$ and the Personal Property Security Act of British Columbia has received third reading but has not yet been proclaimed in force ${ }^{3}$ (the "Ontario PPSA", the "Manitoba PPSA", the "Sask-

I. S.A. 1988 c. P-4.05.

2. R.S.O. 1980, c. 375; R.S.M. 1987, c. P-35; S.S. $1979-80$, c. P-6.1; R.S.Y.T. 1986 c. P-3.2.

3. S.B.C. 1989, c. 36 . 
atchewan PPSA" and the "British Columbia PPSA", respectively). While aspects of the legislation vary from province to province, the fundamental concepts are similar. Alberta, therefore, enters the PPSA era, not in a jurisprudential vacuum as did Ontario when its legislation was proclaimed in force in 1976, but with a wealth of jurisprudence and academic commentary to aid in the interpretation and application of the Act. The Personal Property Security Amendment Act" (the "Amendment Act") was given Royal Assent on July 5, 1990. The amendments are largely of a housekeeping nature, but a number of the changes are significant. This paper will discuss both the PPSA and the Amendment Act and, unless otherwise indicated, references to the PPSA or the Act include the Act as amended by the Amendment Act.

The PPSA adopts a new set of concepts applicable to transactions falling within its purview. Among the key concepts are "security interest", "attachment" and "perfection". While these terms are not foreign to practitioners in Alberta as they are frequently used in pre-PPSA jurisprudence, they take on new, precise meanings in the Act. The Act is intended to nullify distinctions between different types of security interests such as conditional sales, financing leases and floating charges and may nullify the distinction between legal and equitable charges. This is accomplished by introducing the all-encompassing concept "security interest" and by enacting a set of priority rules applicable to all such interests. Jurisprudence in PPSA jurisdictions indicates that this has not been achieved without resistance. It is difficult to cleanse any system of deeply-rooted common law concepts. It is particularly difficult to do so in situations such as this where the legislation intends only limited eradication.

\section{B. OVERVIEW OF THE PAPER}

This paper will not consider all parts of the new Act. In particular, it will not address Parts 4 or 5 of the Act dealing, respectively, with "Registration" and "Rights and Remedies on Default". The latter introduces a number of important variations to the common law and is clearly a topic of its own. The paper will not address conflicts and will touch only generally upon priorities. The paper will focus on the key new concepts introduced by the Act which will provide background for the more detailed discussions which follow on specific issues of concern to oil and gas lenders. The paper's discussion of fundamental new concepts will be limited to "security interests", "attachment" and "perfection". When discussing these concepts, matters of particular interest to oil and gas lenders will be highlighted.

For organizational purposes, the paper will in part focus on the types of oil and gas assets which are typically taken as security by lenders.

\section{ASSET BASE OF AN OIL AND GAS COMPANY}

Assets of an oil and gas company are typically used to secure advances as follows:

(a) interests in petroleum and natural gas held in fee simple or by lease;

(b) equipment and minor facilities such as wellhead equipment, heaters, compressors, etc.;

(c) major facilities such as gas plants where gas products are separated, treated or processed; 
(d) contractual rights which are not primarily revenue-generating such as operating agreements, joint venture agreements, common stream agreements and first refusal and option agreements;

(e) contractual rights which are revenue-generating, such as a right to receivables under a long or short term product sales agreement or a right to payment in respect of a royalty or profit interest; and

(f) interests in severed or produced petroleum and natural gas substances in pipelines or in storage.

Although many petroleum companies hold petroleum and natural gas interests in fee simple, by far the majority of such interests are held by mineral lease. In Berkheiser v. Berkheiser, ${ }^{5}$ the Supreme Court of Canada characterized the oil and gas lease as a profit à pendre or "an irrevocable license to search for and to win the substance named"' (see page 399). A profit à pendre is an incorporeal hereditament or a form of real property right. Because the property owned cannot be subject to possession, it is incorporeal. According to Megarry and Wade, The Law of Real Property: ${ }^{6}$

The list of incorporeal hereditaments is a varied one, and it includes several curiosities; for it was for historical rather than logical reasons that certain rights were treated as real property instead of personal property. Most of them are, indeed, closely connected with land. But there is no logic in treating a rentcharge (the right to an income charged upon land) as real property and a lease as personal property; yet so it is.

The classification of the mineral lease as a profit à prendre and therefore as realty means that it is excluded from the application of the Act. Section 4(f) provides:

Except as otherwise provided in the Act, this Act does not apply to the following . . .

(f) the creation or transfer of an interest in land, including a lease.

As discussed below, this does not mean that the Act can be ignored in completing financings where mineral leases constitute the main security. The Act applies to production and the proceeds of production, and may lead to some difficult priority issues between real and personal property claimants. Similarly, though the Act does not apply to major facilities which constitute real property interests because of their annexation to land, again the Act cannot be ignored since such facilities and their component parts could constitute fixtures which are specifically dealt with in the Act (see Part VII below).

All of the other categories of assets referenced above constitute personal property. Security interests in personal property are directly within the ambit of the Act. The paper will discuss these assets and the methods of securing them under the Act.

\section{GENERAL SCHEME OF THE PPSA}

Secured lenders in oil and gas financings often seek to obtain a specific charge or mortgage on certain key assets of the debtor. This does not mean simply charging a producing oil an gas formation. Rather, the true value of the asset is only realized if the security is structured so as to capture the fully-integrated asset. In the typical scenario, this would mean that the security interest should encompass real property

S. [1957] S.C.R. 387.

6. Sth ed. (London: Stevens \& Sons Limited, 1984) at 813. 
interests in mineral leases, contractual rights governing operations, plants, equipment and facilities, contractual agreements governing gathering, transportation, processing and the sale of production and production proceeds.

Effecting an integrated security package is difficult to accomplish under the existing system with the myriad of common law principles and differing statutory regimes. For instance, mortgaging rights under a specific contract is difficult to effect at common law and specific assignments are excluded from the registration provisions of the Assignment of Book Debts Act. ${ }^{7}$ Depending on the structure of the financing, specific assignments of revenues may be registered under the Business Corporations Act of Alberta; ${ }^{8}$ however, this practice is inconsistently followed.

Not only does the Act pertain to security interests in all personal property, it deals with such interests as they are used, transformed, comingled or attached to real or other personal property. The scheme of the Act can be illustrated with hydrocarbons. A security interest in hydrocarbons can be registered under the Act, and the Act sets out rules pertaining to the commingling of hydrocarbon substances and to the proceeds generated by the sale of such substances. Similarly, the Act applies to goods such as oil and gas equipment which become accessions by being joined to other goods or which become fixtures by annexation to real property.

It should be clear from the categories of oil and gas assets referred to above that (except for interests in petroleum and natural gas leases, plant or facilities that constitute interests in real property and possibly certain contracts which create or constitute interests in land) many of the assets typically mortgaged in oil and gas financings such as equipment, contractual rights, proceeds under specific contracts, general accounts receivable and interests in severed hydrocarbons fall within the purview of the Act. The applicability of a registration regime to some of these assets such as equipment and general account receivables is not new; however, even with respect to these assets, the Act sets out new rules that apply to such security interests.

Under the Act, there will be three main registry systems applicable to interests in oil and gas assets:

(a) the registry of interests in Crown leases provided for in the Mines and Minerals Act; ${ }^{9}$

(b) the registry of interests in freehold lands and leases provided for in the Land Titles $A c t ;{ }^{10}$ and

(c) the registry of interests in personal property provided for in the PPSA.

There will be one main registry for personal property in place of the Central, Corporate and Vehicle registries currently in place. This streamlining of registries effected by the Act is efficient and simplifies secured financings. The federallygoverned registration regime for section 178 Bank $A c t^{\prime \prime}$ security is unaffected by the Act. Accordingly, Bank Act searches for notices of intention will still be required.

By taking advantage of the features of the new Act, a secured lender should be able to obtain a more complete security package than was obtainable under the pre-

7. R.S.A. 1980 , c. A-47.

8. S.A. 1981, c. B-15.

9. R.S.A. 1980 , c. M-15.

10. R.S.A. 1980 , c. L-5.

11. R.S.C. 1985 , c. B-1. 
PPSA regime. This paper will highlight methods of constructing this package and illustrates instances in which oil and gas assets do not fit well within the regime.

\section{SECURITY INTERESTS}

\section{A. PRE-PPSA CATEGORIZATIONS}

Alberta's pre-PPSA personal property security regime required the categorization of security interests into such common law concepts as chattel mortgages, conditional sales contracts and assignments of book debts. Depending on the pigeon-hole into which a form of security could be placed, secured parties and debtors had different rights and obligations. Many types of security interests did not fall into a recognized category, leaving the secured party without a method of notifying competing creditors of its interest and without certainty as to the status of its interest as against other competing interests.

One of the major inequities of the pre-PPSA regime is the differing rights accorded to vendors under conditional sales agreements from those enjoyed by chattel mortgagees. Under both the Conditional Sales Act ${ }^{12}$ (sections 3(1) and 4(5)) and the Bills of Sale $\mathrm{Act}^{13}$ (section 5(1) and section 9(1)), registrations by the vendor and chattel mortgagee, respectively, were to occur within 21 days or 30 days of delivery of the chattels or execution of the agreement depending on whether or not the goods were itinerant machinery. Registration by a conditional vendor within the statutory time period gave it priority retroactive to the date of execution of the agreement, ${ }^{14}$ while registration by a chattel mortgagee was effective only from the date of registration. Differences such as this led to the view that it was preferable to sell under a conditional sales contract rather than to sell outright with a chattel mortgage back to the vendor. ${ }^{15}$

\section{B. SECURITY INTEREST AS DEFINED IN THE PPSA}

The PPSA takes a different approach. The Act applies to all transactions which create security interests, regardless of form or who holds title (section 3(1); see, for example, Guntel v. Kocian). ${ }^{16}$

For clarification, section 3(2) states that the following traditional categories of security are within the ambit of the Act: chattel mortgages, conditional sales contracts, floating charges, pledges, trust indentures, trust receipts, assignments, consignments, leases, trusts and transfers of chattel paper where payment or performance of an obligation is secured. However, the categorization of a security interest into any of these recognized interests is not necessary. The Assignment of Book Debts Act, ${ }^{17}$ the Bills of Sale Act, ${ }^{18}$ the Conditional Sales Act, ${ }^{19}$ the Chattel Security Regis-

12. R.S.A. 1980 , c. C-21.

13. R.S.A. 1980 , c. B-5.

14. Klimove v. General Motors Acceptance Corporation (1955), 14 W.W.R. (NS) 463 (Alta. C.A.).

15. See W.F. Bowker et al, "Panel on Bills of Sale, Chattel Mortgages and Conditional Sales Agrements" (1955-61) I Alta. L. Rev. 273.

16. (1985), 5 P.P.S.A.C. 109, [1986] 6 W.W.R. 458 (Man. Q.B.).

17. Supra.

18. Supra.

19. Supra. 
tries $A c t^{20}$ and Division 2 of Part 7 of the Business Corporations Act ${ }^{21}$ (Alberta) are all repealed by the Act. A security interest is defined by the PPSA to be an interest in personal property which secures payment or performance of a obligation.

\section{NON-SECURITY INTERESTS}

Certain types of interests, however, are subject to the PPSA whether or not they secure an obligation. These are:

(a) the interest arising from a transfer of an account or a transfer of chattel paper;

(b) the interest of a person who delivers goods to another person under a commercial consignment; and

(c) the interest of lessors under leases with terms of more than one year.

The foregoing sweeping inclusions would be a major concern to oil and gas companies but for the exclusions in section 4 discussed below.

A rationale for including interests which do not secure an obligation is that they are often merely alternate forms of financing. As well, the registration of such interests does promote certainty.

\section{INTANGIBLES - THE CATCH-ALL CATEGORY}

While the Ontario PPSA defines "security interest" as any interest in personal property which secures an obligation, the Alberta Act has a different structure; it lists a variety of property interests ending with a catch-all category, "intangibles", which is defined as personal property other than the listed interests. Since the other categories are not defined as being limited to personal property, certain categories could conceivably encompass real property interests. To clarify this, the Amendment Act excludes writings providing for fixed charges in specifically described land from the definition of "security" (section 1(1)(oo)) and "instrument" (section 1(1)(u)(v)).

\section{E. SECURITY INTERESTS IN OIL AND GAS ASSETS}

The categories of property in which security interests can be taken are goods, chattel paper, securities, documents of title, instruments, money and intangibles. Generally, in oil and gas financings, security taken will fall within the categories of "goods" and "intangibles". "Goods" consists of tangible personal property other than chattel paper, documents of title, instruments, security and money, while "intangibles" consists of all personal property other than goods and the tangible personal property excluded from the definition of goods. Severed hydrocarbons in pipelines or storage, oil and gas equipment and facilities, and any tangible property that is not real property would be goods within the meaning of the Act. Interests in personal property leases and contractual rights under oil and gas agreements such as operating agreements, participation agreements, unit agreements, joint venture agreements, general accounts and production sale agreements or other revenue generating agreements whether specific or not would constitute intangibles within the meaning of the Act. The relevance of this categorization is that (aside from temporary

20. S.A. 1983 , c. C-7.1.

21. Supra. 
perfection) security interests in goods can be perfected by possession (section 24(1)(a)) or registration (section 25), but holders of security interests in intangibles must register to perfect their interests.

The categorization of interests does not limit the scope of the definition of security interest; a security interest can be taken in any personal property interest which the secured party and the debtor can create.

\section{F. ILLUSTRATIONS OF SECURITY INTERESTS}

A review of some recent cases from PPSA jurisdictions illustrates the flexibility of the security interest concept. In Guntel v. Kocian, ${ }^{22}$ the Manitoba Court of Queen's Bench found that the following words created a security interest which required registration under the Manitoba statute:

I, Brian Ward owe Fay Kocian \$7,699.99 plus the interest of the Bank of Nova Scotia for 1979 GMC, truck SETCS249B517842.

Clearly, no formal documentation or wording was required to create a security interest. Labelling a security interest a purchase-money security interest is not determinative; security interests are determined by substance, not form, and many types of security interests can be created in the same document. ${ }^{23}$ An assignment of monthly payments from an estate has been found to constitute a security interest, ${ }^{24}$ as was delivery of documents of title to secure repayment of a loan..$^{25}$ Purchase contracts, including COD contracts, where title is reserved until payment in full is made likewise created a security interest. ${ }^{26}$ Rights to deficiency payments under a government program have been found to be subject to a security interest in all of the debtor's present and future property and proceeds therefrom. ${ }^{27}$ However, a trustee's right to satisfy a liability owing to it from the trust beneficiary out of trust property was held not to be a security interest ${ }^{28}$ as this right existed independently of a written agreement.

Participation interests will be governed by the PPSA as they are interests in intangible personal property. A participation certificate has been found to be security within the meaning of the Manitoba PPSA ${ }^{29}$ While the Alberta Act has a more restrictive definition of security (section 1(1)(oo)), it is likely that a participation certificate would fall within that definition, making it possible for a lender to perfect a security interest in the certificate by possession. However, a prudent lender should still register a financing statement.

While the definition of security interest does not include rights in after-acquired property, the Act contemplates attachment of security interests in after-acquired

22. Supra, note 16.

23. Clark Equipment of Canada Ltd. v. Bank of Montreal, [1984] 4 WWR 519, 8 DLR (4th) 424 (Man. C.A.).

24. Re Grogan (1982), 35 O.R. (2nd) 529, 2 P.P.S.A.C. 45 (S.C.).

25. Friend v. Bitter (1979), 1 P.P.S.A.C. 326 (Ont. C.C.).

26. Banque Nationale de Paris (Canada) v. Pine Tree Mercury Sales Lid (1983), 3 P.P.S.A.C. 51, 42 O.R. (2d) 303 (Cty. Ct.); Royal Trust Corporation of Canada v. No. 7 Honda Sales Lid. (1988), 8 P.P.S.A.C. 238, 35 B.L.R. 386 (Ont. Div. Ct.).

27. Agricultural Credit Corp. of Sask. v. Yaddof (1988), 8 P.P.S.A.C. 234 (Sask. Q.B.).

28. Re Berman (1979), 1 P.P.S.A.C. 81, 8 B.L.R. 143 (Ont. C.A.).

29. Boyce Estate (Trustee) v. The Royal Bank (1985), 6 P.P.S.A.C. 127 (Man. Q.B.). 
property (section 13(1)) and numerous cases have recognized security interests in after-acquired property (see, for example, Agriculture Credit Corporation of Saskatchewan v. Yaddof; ${ }^{30}$ Bank of Nova Scotia v. The Royal Bank $;{ }^{31}$ Euroclean Canada Inc. v. Forest Glade Investments Ltd. ${ }^{32}$ Re Huxley Catering Ltd. $\left.{ }^{33}\right)$. One potential pitfall in attempting to secure after-acquired property lies in the requirement that certain types of property be described by serial number. The Saskatchewan Court of Appeal, in Bank of Nova Scotia v. The Royal Bank, held that an after-acquired property clause in a general security agreement was not effective against two trucks which the debtor purchased after executing the security agreement because security interests in motor vehicles were required by the Saskatchewan PPSA regulations to be described by year, make, model and serial number. The Alberta regulations only require that serial number goods, as defined in the regulations, which are consumer goods, be registered by serial number (section 26). Thus, describing after-acquired serial number goods will not be as difficult in oil and gas financings.

While intention of the parties was relevant in determining whether certain types of security interests were governed by the Ontario PPSA, because of section 2(2)(ii) of that Act, intention is not a relevant factor in the Alberta Act. As long as an obligation is secured by a personal property interest, the PPSA governs the security interest, unless the Act explicitly excludes the interest.

\section{G. EXCLUSIONS FROM THE PPSA}

The far-reaching scope of the PPSA is limited by an extensive list of exclusions which are set out in section 4 of the Act. These exclusions are of particular importance to the oil and gas industry since, without them, the Act would apply to many routine transactions. The opening exception found in section 4 is unclear. Likewise, there is some uncertainty in the meaning of the words "does not apply": do they merely mean that one is not required to register exempted interests, or that registration of exempted interests is void? Section 4 of the Act commences as follows:

Except as otherwise provided in this Act, this Act does not apply to the following. . . .

The following is a discussion of some of the specific exclusions:

(a) Liens, section 4(a): a lien, charge or other interest given by an Act or rule of law in force in Alberta. In the oil and gas context, this would include common law and statutory liens arising for work done on a well or facilities site;

(b) Bank Act security, section 4(b): security agreements which are governed by Division B of Part V of the Bank Act $t^{34}$ (i.e. sections 177 and 178 assignments). This exclusion will no doubt generate much discussion among oil and gas practitioners. Section 178 assignments, which apply to "goods" and "products of the quarry and mine", are of some relevance in oil and gas financings; however, section 177 assignments, which pertain specifically to loans on the security of hydrocarbons, will be focused on in this paper.

30. Supra, note 27.

31. (1987), 42 D.L.R. (4th) 636, 8 P.P.S.A.C. 17, 58 Sask. R. 304 (Sask. C.A.).

32. (1985), 4 P.P.S.A.C. 271,46 O.R. (2d) 14 (Ont. C.A.).

33. (1982), 2 P.P.S.A.C. 22, 34 C.B.R. (NS) 274 (Ont. S.C.).

34. Supra, note 11. 
Until recently, section 177 assignments constituted the primary security used in oil and gas financings. Today, there is a growing tendency for lenders to prefer non-Bank Act security. This trend in part has emerged as a result of changes to the registration regime provided for in the Mines and Minerals Act. ${ }^{35}$ Prior to December 16th, 1981 , the Crown registration system only permitted registrations by Canadian chartered banks holding Bank Act security. Canadian chartered banks, therefore, had a tight hold on petroleum industry financings.

Most practitioners regard section 177 Bank Act security as covering the real property interest in the mineral lease, but its reach is broader than that. Section 177 specifically refers to security on hydrocarbons, actual permits or licences to obtain and remove hydrocarbons, equipment and casing used in extracting, mining or producing and storing hydrocarbons and any rights in any of the foregoing. Clearly, section 177 security covers personal property in addition to real interests. This leads to many questions: Can section 177 lenders register under the Act? What qualifications are required to solicitors' opinions? As well, competing priority issues will arise between security taken under the Bank Act and security interests covered by the Act. These and other related issues are discussed in detail in Part VIII of this article;

(c) Rights to payment under executory contracts, sections 4(e) and (h): the transfer of an interest in an unearned right to payment under a contract to a transferee who is to perform the transferor's obligations under the contract (section 4(e)). The Act applies to a transfer of an account or a monetary obligation whether or not it secures payment or performance of an obligation. Applied literally, this would mean that the Act applies to transfers and assignments of interests in gas contracts and other oil and gas revenue generating agreements which are typically transferred in oil and gas asset sales. The exclusion contained in section 4(e) makes it clear, however, that the Act does not apply to executory contracts. This concern may also be covered by section $4(\mathrm{~h})$ which excludes a sale of accounts as part of a sale of the business out of which they arose, "unless the vendor remains in apparent control of the business after the sale". The application of this section is less clear in an asset sale since asset sales may not constitute a sale of "the business". Neither of the exclusions easily applies to the assignment of a royalty, net profits or other oil and gas revenue interest. Arguably in this situation, there is no performance required by the transferee and no business being sold;

(d) Interests in land, section 4(f): the creation or transfer of an interest in land, including a lease. As discussed above, this exclusion applies to mineral leases which in law, according to Berkheiser v. Berkheiser ${ }^{36}$ constitute real property interests in the nature of a profit a pendre. The reference in section 4(f) to a "lease" is nevertheless problematic. Undoubtedly, the drafters intended the reference to apply to ordinary leases of surface land; however, in law, it is arguable that neither the creation nor the transfer of a leasehold interest constitutes the creation or transfer of an interest in land. The legal characterization of leasehold interests has always been difficult. They stand out as misfits. 
A lease of real property constitutes "chattels real" and is most typically characterized in law as personalty. Megarry and Wade state: ${ }^{37}$

In general, all interests in land are real property, with the exception of leaseholds (or "terms

of years"), which are classified as personalty.

They conclude that "leaseholds are still therefore, personalty in law"; and

(e) Right to payment connected to land, section $4(\mathrm{~g})$ : the creation or transfer of an interest in a right to payment that arises in connection with an interest in land, including an interest in rental payments payable under a lease. This drafting is imperfect for the same reasons set out above in the discussion of section 4(f). Would the exclusion extend to assignments of oil and gas royalties or revenue interests or security interests in the foregoing so as to solve the concern referenced in the discussions of sections 4(e) and (h)? It is arguable that while many oil and gas revenue interests are not interests in land, they arise "in connection with" mineral leases which are interests in land. Clearly, this is only an arguable position.

\section{ATTACHMENT AND PERFECTION}

\section{A. GENERAL}

The Act introduces the concepts of attachment and perfection which determine the extent of a secured party's rights. "Attachment" occurs when the secured party acquires a recognized security interest in the collateral (i.e. all steps necessary to the creation of a security interest have occurred). "Perfection" occurs when the secured party has taken all action required by the Act to maximize its rights under the Act. It has been described as "a term of art used to define the time when the secured party has obtained the greatest bundle of rights under the statute with respect to the collateral" '. ${ }^{38}$ While attachment determines the secured party's rights to enforce its security interest, either against the debtor or against third parties, perfection determines priority; the general rule is that perfected interests have priority over unperfected interests (see section 35(1)).

\section{B. ATTACHMENT}

Under the Alberta PPSA, attachment may occur in two stages. As between the parties to the security agreement, it occurs when value is given for the security interest and the debtor has rights in the collateral, unless the parties otherwise agree (section 12(1)). However, in order for the attached security interest to be effective against third parties, the secured party must also obtain possession of the collateral or the debtor must execute a security agreement containing a sufficient description of the collateral (section 12(1)(c)).

Value means sufficient consideration for a contract but includes antecedent debts and liabilities (section 1(1)(tt)). Thus, an unsecured creditor may take security for existing indebtedness without providing additional advances or consideration.

37. Supra, note 6 at 10.

38. Richard H. McLaren, Secured Transactions in Personal Property in Canada, 2nd ed. (Toronto: The Carswell Company Limited, 1989) at 3-3. 
Determining whether the debtor has rights in the collateral is more difficult. It is not necessary for the debtor to have title to the collateral (s. 3(1)(a)), but it must have some degree of rights. ${ }^{39}$ In Euroclean Canada Inc. v. Forest Glade Investments Ltd. ${ }^{40}$ Houlden J.A. (with whom Blair J.A. concurred) adopted McLaren's and De Jong's analysis ${ }^{41}$ that "rights in the collateral" is not limited to legal or beneficial ownership but includes a variety of interests. The majority of the Court of Appeal concluded that a purchaser of goods pursuant to a conditional sales contract who had not yet made any payments toward the purchase price had rights in the goods and could grant a security interest in respect of those goods. In Rogerson Lumber v. Four Seasons Chalet Ltd. ${ }^{42}$ the Ontario Court of Appeal found that a conditional sale purchaser who had not paid any portion of the purchase price did not have an interest which could be assigned to its bank under section 178 of the Bank Act. It appears that a PPSA security interest can attach to a lesser bundle of rights than can a section 178 assignment.

\section{POSTPONED ATTACHMENT}

Section 12(1) of the PPSA, as originally passed, mirrored the Ontario, Manitoba and Saskatchewan PPSA's in stating that a security interest attached once the specified conditions are met "unless the parties intend it to attach at a later time". Because the test for postponed attachment was subjective, depending on the parties intentions, it was difficult to say with any degree of certainty whether an interest had attached. The courts, however, resolved the following questions:

1. The fact that securities which are subject to a security interest are not freely transferable does not mean that the security interest does not attach until the securities are registered in the name of the secured party. ${ }^{43}$

2. A floating charge does not manifest the parties' intention to delay attachment nor does it create a presumption of delayed attachment. ${ }^{44}$

3. A negative covenant against granting security other than purchase-money security did not manifest an intention to defer attachment as, if the parties intended that the security interest not attach until default occurred, a negative covenant would not be necessary. ${ }^{45}$ The deferred interest attaching at the time specified in the agreement suggests that a time for attachment must be specifically named or else be capable of determination, but as this is not expressly stated, it is possible that arguments in favour of implied deferred attachment could still be made. However, when the new provision is contrasted with wording in the Act as originally introduced, one can only conclude that the drafters intended to make implied deferral more difficult to sustain.

The 1990 amendment to the PPSA, however, may clarify the deferral mechanism, using the words "unless the parties specifically agree in writing to postpone the time

39. Re Country Kitchen Donutes Ld. (1980), 1 P.P.S.A.C. 177 (Ont. S.C.).

40. (1985), 4 P.P.S.A.C. 271 at 282 (Ont. C.A.).

41. Secured Transactions in Personal Property in Canada, 1st ed. (Toronto: The Carswell Company Limited, 1979) at 2-6.

42. (1980), I P.P.S.A.C. 160 (Ont. C.A.).

43. Re MC United Masonry Lid. (1983), 40 O.R. (2d) 330, 2 P.P.S.A.C. 237 (C.A.).

44. Royal Bank v. G.M. Homes Inc. (1984), 4 P.P.S.A.C. 116 (Sask C.A.) and Roynat Inc. v. United Rescue Services Lid. (1982), 2 P.P.S.A.C. 49 (Man. C.A.).

45. Supra, note $\mathbf{4 0 .}$ 
for attachment in which case the security interest attaches at the time specified in the agreement".

The fact that a charge is floating in nature does not affect attachment; section 12 specifically includes floating charges in setting out the conditions precedent to attachment. Thus, the holder of a floating charge can perfect its attached interest by registering a financing statement, obtaining priority as set out in the Act from the date of registration over all assets, from time to time, within the charge. As the debtor acquires new assets which fall within the floating charge, the charge will attach, provided that value has been given for the security interest.

\section{ATTACHMENT AND AFTER-ACQUIRED PROPERTY}

A security interest may attach to after-acquired property if the security agreement provides that the interest attaches to after-acquired property. McLaren theorizes that this creates a legal floating charge: ${ }^{46}$

\footnotetext{
. . . the after-acquired property clause permits future tangible and intangible collateral to be swept into the secured collateral base. It permits flexible financing under the Act which, when combined with the future advance [s. 14(1)] and the proceeds interest, permits the security interest to encompass a constantly shifting collateral base under one security agreement. The Act in effect creates a floating lien but with a legal interest rather than an equitable one. . . a secured party may take a security interest which

"floats" over all of his debtor's present and future assets (footnotes omitted).
}

A security interest in after-acquired property attaches to the new property as soon as the debtor acquires its interest in the new property (provided that the other section 12 conditions are met) (see, for example, Re Huxley Catering Ltd. ${ }^{47}$ in which an afteracquired property clause in an assignment of book debts was found to attach to each book debt as it "came into being", and $R e\left(U_{r m a n}^{48}\right)$.

Section 14(1) expressly permits lenders to secure future advances, even where making future advances is within the discretion of the lender (section 1(1)(s)). If the security agreement provides that the security interest attaches to future property of the debtor, the security interest will attach to the debtor's new property once the three conditions set out in section 12 have been met (i.e. essentially, on acquisition of the property) (section 13). Pursuant to section 35(4), future advances obtain the priority position of the first advance. Where there is a deficiency in a security agreement which inhibits attachment, the security interest will attach upon rectification of the deficiency (i.e. upon satisfaction of the section 12 conditions). ${ }^{49}$

It is clear from the foregoing discussion that the concepts and mechanisms established by the Act are particularly suited to inventory financings. McLaren's concept of the floating lien involving a legal interest is apt.

\section{E. PERFECTION}

As stated above, "perfection" has been defined as "the greatest bundle of rights under the statute with respect to the collateral"..$^{50}$ When a creditor perfects its security interest, it obtains rights in the collateral which are superior to those of creditors who

46. Supra, note 38 at $2-14$.

47. (1982), 2 P.P.S.A.C. 22 at 26 (Ont. S.C.).

48. (1983), 44 O.R. (2d) 248 (C.A.).

49. J.I. Case Credit Corporation v. CIBC (1985), 5 P.P.S.A.C. 181 (Sask. Q.B.).

50. Supra. note 38 . 
have not perfected their security interests (section $35(1)(c)$ ), judgment creditors and trustees in bankruptcy (section 20(1)).

To be perfected, a security interest must have attached and all steps under the Act for perfection must have been completed (section 19(a) and (b)). The order of occurrence of attachment and completion of the steps for perfection is irrelevant (section 19; see also R.C. United Masonry Ltd. ${ }^{51}$ ) and priority of a perfected interest dates from the date of completion of the steps necessary for perfection (i.e. possession or registration, as described below), regardless of the date of attachment (section 35 (1)(a)(i) and (ii)).

The fact that a security interest can be registered before it attaches offers a lender flexibility at the closing of a financing transaction. It permits a lender to put its security in place and ascertain prior security interests before actually advancing funds. If the lender is not satisfied with its priority position and, if satisfaction is a condition precedent to the funding obligation, the lender can refuse to advance funds.

\section{F. PERFECTION BY POSSESSION}

The PPSA permits perfection in three ways: possession, registration and temporary perfection under specific provisions. Security interests in all types of collateral except intangibles and non-negotiable documents of title may be perfected by possession. Section 24 provides that possession of collateral by the secured party perfects a security interest in goods, chattel paper, securities, negotiable documents of title, instruments and money. Accordingly, to err on the side of caution, one should file financing statements in situations where duplicate leases and duplicate certificates of title are hypothecated as security and not merely rely on possession of these documents.

Perfection by possession is only effective as long as the creditor holds the goods as collateral (section 24). If a creditor repossesses goods which are subject to its security interest in full satisfaction of the underlying debt, it may possess the goods in an ownership capacity, and not as collateral. Many cases, however, have found possession for the purposes of realization to be sufficient to perfect security interests (see, for example, Re Charron; ${ }^{52}$ Re Olmstead; ${ }^{53}$ Sifton Credit Union Lid. v. Barber; ${ }^{54}$ and Hundt v. Fenton. ${ }^{55}$ ) In the Amending Act, section 24(1) was revised to state that holding property as a result of seizure or repossession is not possession for the purpose of perfecting a security interest.

There is conflicting authority as to whether possession by a receiver constitutes possession by the secured party. In Sifton Credit Union, ${ }^{56}$ certain assets are referred to as being "in the actual physical possession of the plaintiff, its receiver or solicitor" (page 16), yet this was found to be possession by the debtor. However, where a security agreement provides for the appointment of a receiver on default and states that the receiver acts as agent for the debtor rather than the secured party, possession

51. (1983), 40 O.R. (2d) 330, 2 P.P.S.A.C. 237 (C.A.).

52. (1984), 4 P.P.S.A.C. 228, 54 C.B.R. (NS) 301 (Ont. S.C.).

53. (1984), 4 P.P.S.A.C. 220 (Ont. S.C.).

54. [1986] 4 W.W.R. 341, 6 P.P.S.A.C. 9 (Man. Q.B.).

55. (1986), 5 P.P.S.A.C. 259 (Ont. S.C.).

56. Supra, note 54 . 
of the collateral by the receiver does not perfect the secured party's security interest because the receiver is the debtor's agent. ${ }^{57}$ This position is reinforced by section 24(2) which provides that a secured party is deemed not to be in possession of collateral which is in the apparent possession or control of the debtor or an agent of the debtor. Mr. Justice Morden, in Sperry, quotes Mr. Justice Holden in Peat Marwick v. Consumers' Gas Co. ${ }^{58}$ as follows:

If the bank chooses to provide in its debenture that the receiver and manager shall be deemed to be the agent of the debtor company, then it must not only take the benefits, but it must also accept the detriments which flow from such a provision.

The original form of the Ontario PPSA did not permit perfection by registration of securities, instruments (including letters of credit and advices of credit) and documents of title. ${ }^{59}$ According to Professor Ziegel, this is because the Ontario PPSA was based on Article 9 of the Uniform Commercial Code and the general practice in the United States is for creditors to take possession of these types of assets. Where shares in a subsidiary or related company were taken as part of a security package, the lender had to take possession of the share certificates. Physical possession of the certificates perfected the interest even where the certificates are not fully transferable: Re MC United Masonry Ltd. ${ }^{60}$ However, the Alberta PPSA (as does the Ontario PPSA, 1989) permits perfection by registration of securities, instruments and documents of title.

If a lender wishes to obtain a security interest in its borrower's participation interests, it should be able to perfect its interest by taking possession of the participation certificate since such a certificate will likely be found to be a "security" within the meaning of section 1(1)(oo). In Boyce Estate (Trustee) v. The Royal Bank of Canada, ${ }^{61}$ a participation certificate was found to be a security within the meaning of the Manitoba PPSA. The participation certificate under consideration in Boyce had the following attributes: the holder was entitled to a $1.66 \%$ interest in production from an oil and gas program and the interest was only transferable on written notice to the issuing company accompanied by surrender of the certificate, the signing of a receipt for the production purchase agreement by the transferee and the payment of a registration fee. However, the definition of "security" in the Alberta PPSA is narrower than in the Manitoba Act, requiring that it be "one of a class or series or by its terms divisible into a class or series". While the use of the terms "class" and "series" connotes equity shares, a participation interest represents an interest divided into units. There is no judicial consideration of this provision (which is also in the Ontario PPSA definition of "security") but one can expect that an interest which has attributes similar to those of a share will constitute a security.

Participation certificates representing an entitlement to production proceeds are frequently taken as security in oil and gas financings. Where the participation certificate falls within the definition of a security, it is not an account. As discussed earlier, according to section 3, the Act applies to transfers of accounts even where they do not secure payment or performance of an obligation.

57. Sperry Inc. v. C.I.B.C. (1985), 50 O.R. (2d) 267 (C.A.).

58. (1980), 29 O.R. (2d) 336 at 346.

59. Ziegel, "Perfection by registration, instruments, securities, documents of title and the Personal Property Security Act, 1989" (1989), Can. Bus. L. J. 242.

60. Supra, note 51.

61. (1985), 6 P.P.S.A.C. 127 (Man. Q.B.). 


\section{G. PERFECTION BY REGISTRATION}

Perfection by possession is much more common than perfection by registration. A review of the case law on perfection by possession leads one to the conclusion that possession is relied upon in the case of deficient registrations or where the secured party has failed to register at all. Registration, however, will be the method of choice for conscientious lenders.

Section 25 , an oddly-worded provision, authorizes perfection by registration of a financing statement. It reads "[s]ubject to section 19, registration of a financing statement perfects a security interest in collateral". Section 19 provides that a security interest is perfected when it has attached and the steps necessary to perfect the interest are completed. Read together, this would seem to mean that registration, when combined with attachment, yields a perfected security interest. While it does not foreclose the possibility of additional steps being required, the Act does not currently impose any.

Once a security interest is perfected, it continues in its perfected state as long as it is renewed as required. Because a financing statement does not describe the details of the transaction, a lender is not required to register a financing change statement every time a loan is re-written, provided that its security interest and the collateral do not change. In TransCanada Credit Corporation Ltd. v. Royal Bank of Canada, ${ }^{62}$ the borrowers charged a truck as security for a loan by way of a chattel mortgage. The loan was re-written twice and each time that it was re-written, the chattel mortgage was registered. Before the first re-writing, the borrowers pledged the truck to TransCanada. TransCanada argued that each re-write was a new loan, extinguishing the prior loan and the security interest. Geatros J. rejected this argument, concluding that, because the PPSA introduces a notice filing system in which detailed information is to be obtained from the secured party (see Touche Ross Ltd. v. Royal Bank ${ }^{63}$ ), the lender was not required to register a financing statement whenever the loan was re-written.

Oil and gas lenders, who frequently rewrite and restructure debt obligations, will appreciate this approach as it will eliminate the problem of determining whether registrations in respect of the restructuring ought to be effected. This approach will also help ease the cluttering of the registry system by lenders who have adopted the practice of taking and registering identical security wherever a loan agreement is amended.

Where the nature of the secured party's security interest changes, a new financing statement is required and priority is determined from the date of the new statement. In $C I B C$ v. International Harvester Credit Corporation, ${ }^{64}$ a lender converted its security from a lease to a conditional sales contract. Because the two interests were not identical, the later conditional vendor's interest did not have priority retroactive to the perfection date of the prior lease. Further, where a lender consolidates and expands its security, it should maintain the earlier registrations because the consolidated security will only have priority from its perfection date. In Birch Hills Credit Union Ltd.

62. (1985), 5 P.P.S.A.C. 1 (Sask. Q.B.).

63. (1984), 3 P.P.S.A.C. 280, 51 C.B.R. (NS) 253, [1984] 3 W.W.R. 259, 31 Sask R. 131, (Sask. C.A.).

64. (1985), 4 P.P.S.A.C. 329 (Ont. H.C.) reversed on other grounds (1986), 6 P.P.S.A.C. 273 (Sask. C.A.). 
v. $C I B C,{ }^{65}$ a credit union held security interests pursuant to security agreements dated February 18, 1982 and August 12, 1982, each of which was duly registered. On March 24, 1984, the debtor's loans were consolidated and he executed a new consolidating security agreement. Additional collateral was added and the repayment terms were amended. The credit union discharged its first two registrations and then registered its new security interest. CIBC had registered security interests after the credit union's first two registrations, but before the consolidating registration. The Saskatchewan Court of Appeal held that CIBC had priority because of the discharge of the credit union's earlier registrations. Had the earlier registrations not been discharged, the credit union should have had priority with respect to the collateral described in those registrations.

The form of financing statement does not require identification of the underlying documentation, with one exception: lenders are required to indicate whether the registration covers a trust indenture. Accordingly, where a trust indenture creates the security interest and the trust indenture is replaced, a new financing statement should be registered as a precautionary measure. It could be argued that the registration relates only to the trust indenture in existence at the time of the first registration. However, if a supplemental trust indenture is used, rather than a replacement trust deed, the secured party can file a financing charge statement and retain its priority position.

If a creditor allows its security interest to lapse and subsequently re-registers a financing statement, a creditor which perfects its security interest during the interval in which the first security interest has lapsed will have priority. ${ }^{66}$

\section{H. ACTUAL NOTICE}

Although it is not without exception (see, for example 529617 Ontario Ltd. v. Concord Inn Motel Inc. ${ }^{67}$ ) courts have been consistent in holding that where a creditor who has perfected its security interest has actual knowledge of a prior unperfected security interest at the time it acquired its interest, its perfected interest will prevail over the prior existing unperfected interest (see Bank of Nova Scotia v. Gaudreau; 68 Northland Bank v. Flin Flon Mines Ltd.;69 National Trailer Convoy of Canada Ltd. v. Bank of Montreal; ${ }^{70}$ and Robert Simpson Co. v. Shadlock $\left.{ }^{71}\right)$. These cases are consistent with the theory that the priorities scheme contained in the PPSA is exhaustive and comprehensive concerning security interests within its domain. The priorities sections of the Act do not specifically refer to knowledge of the parties, while rights granted under other sections (for example, section 38(3) regarding accessions, sec-

65. [1988] 5 W.W.R. 592, 52 D.L.R. (4th) 113, 8 P.P.S.A.C. 199 (Sask. C.A.); affirming [1987] 6 W.W.R. 265, 7 P.P.S.A.C. 250.

66. Re Triad Financial Services and Thaler Metal Industries Lid. (1979), 240 R. (2d) 423, 1 P.P.S.A.C. 44; affirmed (1979), 270 R. (2d) 506, 106 D.L.R. (3d) 706; leave to appeal to the Supreme Court of Canada denied (1980), 270 R. (2d) 506n.

67. (1988), 8 P.P.S.A.C. 265 (Ont. Dist. Ct.).

68. (1984), 48 O.R. (2d) 478, 27 B.L.R. 101, 4 P.P.S.A.C. 158 (Ont. H.C.).

69. (1987), 38 D.L.R. (4th) 49, 58 Sask. R. 21, 66 C.B.R. (NS) 197 (Q.B.); affirmed (1987), 46 D.L.R. (4th) 766, 62 Sask. R. 308, 66 C.B.R. (NS) 197n (Sask. C.A.).

70. (1980), 1 P.P.S.A.C. 87, 10 B.L.R. 196 (Ont. S.C.).

71. (1981), 31 O.R. (2d) 612, 13 B.L.R. 312, 37 C.B.R. (NS) 52, 1 P.P.S.A.C. 272, 119 D.L.R. (3d) 417 (Ont. S.C.). 
tion 31(3) and (4) regarding transfers of instruments, securities and negotiable documents of title, and section $20(1)(c)$ regarding transfers of personal property before a security interest is registered) can be lost if the party who holds a perfected security interest has knowledge of a competing prior interest.

In spite of the authority in support of the proposition that knowledge is irrelevant between competing security interest holders, the opposing view deserves close scrutiny as it is founded in deeply-rooted equitable principles which are not easily set aside. In the Concord Inn ${ }^{72}$ case, Stortini J. of the Ontario District Court declined to follow the prior decisions of the Ontario Courts in Shadlock, ${ }^{73}$ Gaudreau $^{74}$ and National Trailer Convoy, ${ }^{75}$ preferring the view that the PPSA does not expressly oust the doctrine of actual knowledge. He cites the Supreme Court of Canada decision in United Trust Co. v. Dominion Stores Ltd ${ }^{76}$ for the proposition that the doctrine of actual knowledge cannot be abrogated from property law without clear and unequivocal terms. However, while there is some merit in applying the United Trust principles, Stortini J. did not lay the foundation for such an application by establishing the entrenched nature of actual notice in personal property law. The United Trust case considered the question of whether the Lands Titles Act ${ }^{7}$ of Ontario abrogated the principle that actual notice is effective to encumber the registered title holders' estate. In the course of rendering the majority judgment, Spence J. stated: ${ }^{78}$

There is no doubt that such doctrine as to all contractual relations and particularly the law of real property has been firmly based in our law since the beginning of equity.

Whether such a foundation exists or not is beyond the scope of this paper and we wish only to point out that the issue of actual notice has not been completely resolved.

Section 47 of the PPSA may also shed some light on this issue. It provides that registration of a financing statement is not constructive notice or knowledge of its existence or contents to third parties. Accordingly, third parties are not deemed to have notice of or to be bound by security registered in the system. The existence of this provision is inconsistent with the concept that the entries recorded on the registry constitute the complete set of adverse interests since one would expect that if this were the intention, parties would in fact be bound by entries on the registry and would be deemed not to have notice of any other interests not reflected on the registry. This, for example, is the premise of the Alberta land titles registry system and the mirror principle which it embodies.

\section{TEMPORARY PERFECTION}

In addition to perfection by possession and registration, the Act confers temporary perfected status on secured parties in the following circumstances:

(a) The secured party's interest in instruments or securities remains perfected for the first 15 days of the debtor's possession of the collateral if the secured party returned the collateral to the debtor;

72. Supra, note 67.

73. Supra, note 71 .

74. Supra, note 68.

75. Supra, note 70 .

76. [1977] 2 S.C.R. 915, 1 R.P.R. 1, 71 D.L.R. (3d) 72 (S.C.C.).

77. R.S.O. 1980, c. 230.

78. Supra, note 76 at 952. 
(i) to permit its sale or exchange,

(ii) for the purpose of presentation, collection or renewal, or

(iii) to permit the registration of a transfer;

(b) A secured party's interest in a negotiable document of title or in goods held by the bailee which are not covered by a negotiable document of title remains perfected for the first 15 days of the debtor's possession. If the secured party made the negotiable document of title or the goods available to the debtor to permit;

(i) the sale or exchange of the goods,

(ii) the loading, unloading, storing, shipping or trans-shipping of the goods, or

(iii) manufacturing, processing, packaging or otherwise dealing in a manner preliminary to the goods' sale (section $26(1)(b)$ );

(c) A secured party has a continuously perfected security interest in proceeds for 15 days where the secured party perfected its security without registering a financing statement which describes or includes proceeds (section 28(3));

(d) A secured party has a perfected security interest for 15 days in goods where accounts or chattel paper arising from the sale or lease of those goods have been transferred to the secured party, and the goods are returned to or are repossessed by the debtor, provided that the secured party had perfected its security interest in the accounts or chattel paper (section 29(4));

(e) Where a secured party perfects its security interest under the laws of the jurisdiction in which the goods are situated when the security interest attached to them and the goods are subsequently brought into Alberta, the security interest is continuously perfected if the secured party perfects its security interest under the PPSA by the earliest of 60 days after the goods enter the province, 15 days after the secured party has knowledge that the goods are in the province, or the date on which perfection ceases in the original jurisdiction (section 5(2)); and

(f) Where a debtor moves to another jurisdiction or transfers its interest in the collateral to a resident of another jurisdiction, the perfected interest of a secured party remains perfected in Alberta if it is perfected in the new jurisdiction by the earliest of 60 days after the debtor moves or transfers its interest, 15 days after the secured party has knowledge of the move or transfer, or the ceasing of perfection under the laws of the first jurisdiction (section 7(3)).

Where a security interest is temporarily perfected, the secured party has the benefit of perfection during the specified period, regardless of whether it actually perfects its security interest at the end of the specified period. In Central Refrigeration \& Restaurant Services Inc. v. Canadian Imperial Bank of Commerce ${ }^{79}$ a trustee in bankruptcy cashed cheques in payment of the bankrupt's accounts receivable. The bank had a perfected security interest in the accounts receivable and had a temporarily perfected security interest in the proceeds of these accounts. The trustees argued that because the bank did not ultimately register its security interest in the proceeds, it lost the benefit of temporary perfection. The Saskatchewan Court of Appeal rejected this argument "because the clear language of the section does not support the view that the temporary perfection is invalidated retrospectively if registration does not take place" (see page 267). 


\section{PROCEEDS, CONTINUOUS PERFECTION AND PROCESSED GOODS}

\section{A. THE GENERAL RULE}

The Act provides that where collateral is dealt with so as to give rise to proceeds, the security interest, in certain cases, continues in that collateral and extends to the proceeds. In the context of oil and gas financings, collateral or personal property that is subject to a secuirty interest could include severed hydrocarbons or production equipment. Where such collateral is dealt with so as to give rise to proceeds, the security interest continues to those proceeds.

The concept is set out in section 28 of the Act. Section 28(1) provides:

(1) Subject to this Act, where collateral is dealt with or otherwise gives rise to proceeds, the security interest:
(a) continues in the collateral, unless the secured party expressly or impliedly authorized the deal- ing; and
(b) extends to the proceeds.

\section{B. APPLICATION TO HYDROCARBONS}

Where a lender with a security interest in hydrocarbons supports the marketing efforts of its debtor by authorizing dealings with the hydrocarbons, its security interest extends to the proceeds and ceases to exist in the hydrocarbons. In most oil and gas financings, the lender implicitly, if not explicitly, authorizes processing, treatment and sales of hydrocarbons. For clarity, however, and to avoid future disputes over whether or not this authorization exists, the debtor should explicitly procure the authorization of the secured creditor. An important implication flows from the severing of a secured party's interest in hydrocarbons: the secured party essentially holds substitute security in the proceeds. Because security interests continue in, and can be traced through, the collateral as it is transformed or otherwise dealt with in the course of business by the debtor, the Act confers a substantial benefit on secured lenders.

In addition to creating proceeds, hydrocarbons are often commingled or processed which may result in secured parties holding competing interests in a commingled mass or new product (see the discussion at part IV-6 below). As well, as hydrocarbons are cleared or released from the prior security interests, they in turn are free to be dealt with and financed by the person acquiring an interest in those hydrocarbons at a later stage in their development. In theory, by recognizing hydrocarbons as goods to which a prior security interest is released, the Act permits hydrocarbons to be secured on a stand-alone basis, more effectively constituting valid security for an obligation.

Although these benefits should flow from the PPSA regime, there are conflicting legal principles which must be taken into account, and the PPSA regime itself must be observed closely. The conflicts arise largely from the overlap between real and personal property regimes: what happens to the extent or scope of a secured party's interest in severed hydrocarbons where the interest exists in the underlying real property interest? 
An analysis of several cases on the real property-personal property overlap illustrates the confusion caused by the interaction of the two systems. Re Urman ${ }^{80}$ involved a mortgage broker, Urman, who bought and sold real property mortgages. Urman's bank lender had taken a general assignment of book debts as security for its loan to Urman and had properly filed a financing statement. After Urman defaulted on its loan, the assignees of several mortgages gave notice to the mortgagors instructing the mortgagors to make payments directly to them. A priority dispute developed between the bank as assignee of revenues and the assignees of interests in the mortgages. The Ontario Court of Appeal stated that a mortgagee's right to receive the mortgage money appeared to be an intangible to which the Ontario PPSA applied; however, it found that this was not the correct analysis because the underlying mortgage debt could not be separated from the land on which it was secured. The court concluded that the assignment of the mortgage was to be treated as an interest in land and the priority rules applicable were those governing interests in land, on the basis that priority was attributed to the real property interests because the bank authorized Urman to give good title to the mortgagees and the mortgagees had given notice of their interests to the mortgagor before the bank gave notice of its interest.

The case demonstrates that there is uncertainty as to how the local real and personal property law priority regimes should overlap. The court clearly held that the mortgages under consideration constituted real property interests and that the payment of moneys thereunder could not be severed from the real property interest. To frame the issue as the court did amounted to a separation of the proceeds from the mortgage. Also, implicit in the decision was reasoning to the effect that had the bank not authorized the mortgage sales or had it notified the mortgagors of the assignment of debts, it would have defeated the mortgage assignees, which is inconsistent with the conclusion that the underlying debt cannot be severed from the mortgage.

A similar issue came before the Saskatchewan Court of Appeal in United Dominions Investments Ltd. v. Morguard Trust Co. ${ }^{81}$ where a trust company took a mortgage and assignment of apartment rental payments and properly registered the agreements under the Lands Titles Act of Saskatchewan. ${ }^{82}$ This security was taken before the Saskatchewan PPSA came into force and the trust company did not register the assignments after the Act came into force. Subsequently, United took a second mortgage and an assignment of the rentals and perfected it under the Saskatchewan PPSA. The trust company then served notice on the tenants requesting that rental payments be forwarded to them, and United brought a motion to have the priorities determined. At trial, United's perfected assignment prevailed. The trust company successfully appealed. The Court of Appeal relied on section 22 of the Saskatchewan PPSA which subordinates a security interest in rental payments to an interest in the underlying lease.

Tallis J.A., at page 209, states:

We agree with the appellant Morguard's submission that, in the circumstances of this case, it is entitled to priority with respect to the rent payments for January 1985 and subsequent months. In our opinion section 22 reflects a legislative policy to provide a priority rule to deal with any conflict between a person who acquires "an interest in the lease itself" and the holder of a security interest such as the assignee of rental payments. Under this statutory provision, the priority issue, in the absence of fraud, must be

80. Supra, note 48 .

81. (1985), 5 P.P.S.A.C. 203 (Sask. C.A.).

82. R.S.S. 1978 c. L-5. 
determined in favour of the real property interest. Applying this principle to the circumstances of this case, we hold that Morguard's interest in the leases, including its rights as mortgagee to collect rents payable thereunder, ranks in priority to United's assignment of rental payments registered under the PPSA. Morguard's prior interest under section 22 does not become subordinate merely because United was the first to exercise its right to collect arrears. The conclusion is consistent with our view that, speaking generally, section 22 reflects a legislative policy to uphold the integrity of the Land Titles Registration System if any conflict arises between the Land Titles Act and the PPSA.

It is implicit that absent section 22 of the Saskatchewan PPSA, United would have been successful. Note that Alberta does not have an equivalent of section 22.

Applied in the oil and gas context, the question is whether a mortgage or charge on the underlying mineral lease necessarily extends to the minerals and, if so, how far along the chain it extends. The hydrocarbon lease, being a profit à prendre, is a real property right to enter onto land for the purposes of extracting and taking hydrocarbons. The hydrocarbons are integral to the value of the lease, although, once severed, they are merely goods, which would be subject to the Act. The Supreme Court of Canada in Flintofi v. The Royal Bank of Canada ${ }^{83}$ held that a bank holder of section 179 Bank $\mathrm{Act}^{84}$ security over goods had an interest in the proceeds derived from the goods notwithstanding that its assignment of book debts was deficient. In upholding the bank's entitlement to the proceeds, Judson J. stated at page 635:

Why would any lender who lends for the purpose of enabling another to acquire and manufacture goods permit the sale of goods on which he holds security except on terms that the borrower must bring in the proceeds of the sale of those goods?

This case may be explained on the basis that it applies to the unique Bank Act security considered in that case, but it may have broader implications for all lenders who finance the acquisition and manufacturing of goods.

Section 177 of the Bank Act raises a similar issue as the bank assignee clearly obtains an interest in the severed hydrocarbons by virtue of the authority of the Bank Act. A section 177 assignment provides the bank assignee with security over hydrocarbons or minerals in place or in storage and over equipment and casing used or to be used in extracting, mining or producing, or seeking to extract, mine or produce, and storing any such hydrocarbons or minerals. Where the bank holds the paramount section 177 security, the Bank Act priority regime will likely govern and not that of the PPSA (see Part VIII below for a discussion of this issue). The reasoning of Flintoft may also be applicable. This could be a special advantage to Bank Act assignees.

Given the reasoning in $\mathrm{Re} U r m a n,{ }^{85}$ we can envisage the situation where the assignee of a lease or a real property interest could find itself pitted against the mortgagee of hydrocarbons and proceeds derived therefrom. On what basis would that priority battle be settled? Section 72 of the Act states that if there is a conflict between a provision of the Act and a provision of any other Act, other than an Act for the protection of consumers, the provisions of the PPSA prevail. Does this mean the PPSA priority scheme will prevail over that of the Land Titles Act ${ }^{86}$ or the Mines and Minerals Act ${ }^{87}$ To avoid the jeopardy posed by the foregoing cases, a lender taking security in mineral leases should ensure that it has, as well, properly perfected its interests in the hydrocarbons and proceeds.

83. [1964] S.C.R. 631 (S.C.C.).

84. Supra, note 11.

85. Supra, note 48.

86. Supra, note 10.

87. Supra, note 9. 
These difficult issues might result in complex priority battles between a security holder with security over the underlying asset and persons claiming interests in hydrocarbons and the proceeds therefrom. The second lender who has security on an underlying mineral lease and who wishes to avoid priority battles with a PPSA security interest holder who has security over hydrocarbons and proceeds therefrom granted by the same debtor, should insure that it has done everything required by the Act to perfect its interest along the chain of dealing. However, before one could say that a secured lender in the oil and gas business can now avoid taking costly and cumbersome fixed security on mineral leases and obtain the same benefits by merely taking and perfecting a security interest in hydrocarbons and proceeds therefrom, a number of principles must be better defined and reconciled. Although this priority issue is a real issue, we doubt that it will have enormous consequences. In our view, it will only apply to severed hydrocarbons. Absent an agreement, a secured lender will not be bound by contractual arrangements to dispose of hydrocarbons.

\section{PROCEEDS}

As mentioned in the introduction to this Part, the basic rule applicable to proceeds is set out in section 28(1): where collateral is dealt with or otherwise gives rise to proceeds, the security interest extends to the proceeds. Section 28(1) uses the language "deal with" meaning something broader than merely sales. As well, "proceeds" is defined in section $1(1)(\mathrm{gg})$ to mean:

identifiable or traceable personal property, including fixtures and crops,

(i) derived directly or indirectly from any dealing with collateral or the proceeds of the collateral,

(ii) in which the debtor acquires an interest,

and includes

(iii) a right to an insurance payment or any other payment as indemnity or compensation for loss of or damage to the collateral or proceeds of the collateral, and

(iv) a payment made in total or partial discharge or redemption of an intangible, chattel paper, an instrument or security.

The definition is very broad in that it extends to personal property derived directly or indirectly from any dealing with collateral in which the debtor acquires an interest. Consequently, it should apply to a multistep chain of dealing. If the personal property were equipment, it would extend to replacement or substituted equipment and to the proceeds of sale or insurance.

On the other hand, the definition of proceeds contains a serious limitation in that the proceeds must be "identifiable" or "traceable" personal property. It is not difficult to meet this test in the case of substituted equipment or where the collateral is tangible property; however, where accounts or money proceeds are derived as a result of the dealing, the situation can be far more difficult. Oil and gas practitioners are familiar with the particular difficulties involved in tracing the proceeds of hydrocarbons. Oil and gas companies are often involved in transactions pursuant to which they market production on behalf of others or receive revenue which is attributable to the interest of another person. This can happen in their capacities as operator, manager of a drilling fund, partnership or joint venture or on account of being named agent in a production sales contract. Typically, production revenues generated in any of these capacities are deposited into a general account with all similar deposits and with the company's own revenues. Tracing these interests would involve an extremely difficult application of the equitable tracing rules. 
A security interest holder could alleviate some of these difficulties by insisting upon segregated trust accounts (see General Motors Acceptance Corporation v. Bank of Nova Scotia ${ }^{88}$ ). In general, oil companies firmly resist such suggestions on account of the administrative difficulty involved in managing separate accounts.

In addition, the Act itself places additional restrictions on the application of this section. Section 28(2) states:

A security interest in proceeds is a continuously perfected security interest if the interest in the original collateral is perfected

(a) by the registration of a financing statement that contains a description of the proceeds that would be sufficient to perfect a security interest in original collateral of the same kind,

(b) by the registration of a financing statement that covers the original collateral, if the proceeds are of a kind that are within the description of the original collateral, or

(c) by the registration of a financing statement that covers the original collateral, if the proceeds consist of money, cheques or deposit accounts in banks or a financial institution.

Where the security interest was perfected in a manner other than that referred to above, the security interest in the proceeds is continuously perfected for $\mathbf{1 5}$ days, in which time it should be perfected in accordance with the Act.

The result of the foregoing is that a security interest in hydrocarbons or equipment will extend "continuously" to the proceeds of sale if the financing statement is drafted so that it covers the original collateral and its proceeds. Where proceeds are the same as the original collateral or are money, cheques or deposit accounts, no special registration is required. Section $28(2)$ implies that by registering the appropriate financing statement, an interest in "proceeds" would be perfected. Out of caution, we would suggest that all anticipated proceeds which might be derived from the original collateral should be explicitly covered in the security agreement and in the financing statement.

Once the criteria for a continuous perfection are met under section 28 , priority disputes involving the proceeds will be resolved by looking back to the date of registration of the original financing statement.

\section{PRIORITY RULES}

Special priority rules contained in section 30 of the Act could affect the operation of section 28 and special priority rules applicable directly to proceeds are set out in section 31 . The special priority rules preclude the application of the general residual priority rule contained in section 35 of the Act. Section 35(2) makes it clear that when a priorities dispute concerns a proceeds interest, the relevant date for the purposes of determining priorities is the date established under the residual priority rule for determining priorities between conflicting security interests in the original collateral. According to section 30(2), where goods are sold or leased in the ordinary course of business, the buyer or lessee takes free of any perfected or unperfected security interest whether or not the buyer or lessee has knowledge of it unless the buyer or lessee also has knowledge that the sale or lease constitutes a breach of a security agreement. The security interest presumably would continue in the proceeds, provided they are traceable. As well, according to section 30(6), where goods are sold or leased other than in the ordinary course of business, the buyer or lessee takes free from any security interest in the goods perfected by registration if the buyer or lessee bought or 
leased the goods without knowledge of the security interest and, if the goods are required to be described by serial number, the registration relating to the security interest did not include serial numbers. Section 31 confers special protection and priority on holders of money and negotiable documents and on purchasers of instruments, security and chattel paper over security interests perfected in proceeds under section 28 .

\section{E. SUMMARY}

The secured lender who wishes to take advantage of the continuous perfection rule as it applies to proceeds should, to the extent possible, draft the original security agreement to evidence the intention of creating a trust interest in the "proceeds" derived from the original collateral. As well, where possible, the descriptions in the security agreement and the financing statement registered in respect of the original collateral should extend to anticipated "proceeds" that might be derived from the original collateral. The second party who does not structure its security along these lines faces the risk of a priority dispute with a third party who takes security on an asset or its proceeds at a different point in the chain of its use. The debtor should procure the explicit authorization of the secured party to deal with the secured assets so that persons who acquire interests in the collateral do not have to obtain the consent of the secured lender having security in the original collateral.

\section{F. SECURITY INTERESTS IN PROCESSED OR COMMINGLED GOODS}

One very large obstacle to the financing of hydrocarbons is related to the fact that hydrocarbons become processed, treated and transported, all of which result in the commingling of hydrocarbon substances with other substances, including production belonging to other producers. Once commingled with other substances, the rights of a lender become confused and difficult to determine with any certainty. Section 39 of the Act attempts to deal with those difficulties.

According to section 39(1), a perfected security interest in goods that subsequently become part of a product or mass continues in the product or mass if the goods are so processed, assembled or commingled that their identity is lost in the product. Commingled goods are distinguished from accessions in that they have become so blended or processed into another product that they cannot be feasibly restored to their original state. The Act specifies that the security interest continues in the resulting mass or product.

The Amendment Act provides that perfection of a security interest in goods that subsequently become part of a product or mass is to be treated as perfection of the interest in the product or mass so that a new registration will not be required in respect of the interest in the product. The priority of a perfected security interest which continues in a product is limited to the value of the goods which are subject to the security interest at the time that they became part of the product. This would appear to say that the value is limited to the value of unprocessed goods; the incremental value achieved by processing does not accrue to the security interest holder in the original goods.

With some exceptions applicable to purchase-money security interests, the Act states that if more than one perfected security interest continues in the same product and each was a security interest in separate goods, the security interests are entitled to share in the product or mass according to the ratio that the obligation secured by 
each security interest bears to the sum of the obligations secured by all the security interests. The Amendment Act provides that the obligation secured by a security interest cannot exceed the market value of the goods at the time they become part of the product. Without the clarification provided for in the Amendment Act, there would be great difficulty in applying the formula set out in section 39(2). It appears that each security interest holder having an interest in the product is entitled to priority based upon the proportionate share which it contributed to the product to the total market value of all other original goods contributed to the product.

It would appear that the objective of the formula is to ensure that all secured parties are paid in full where possible and, to the extent that this does not occur, each shares proportionately based upon their investment in the product.

Statutory recognition of continued security interests in commingled production is clearly a benefit for lenders attempting to secure interests in hydrocarbons. The formula suggested by the Act appears workable where the product to which a good is contributed is static, as would be the case of production stored in a tank. However, where there is a constant flow of product, we can expect that a secured lender will first have to demonstrate that its portion remains part of the product before it will be allowed to apply the formula. In other words, the common law tracing rules would apply first. The sophisticated metering and accounting processes in place in the oil and gas industry should facilitate this effort and will hopefully produce a workable formula for determining priority interests in the commingled product.

\section{PRIORITIES OVERVIEW}

\section{A. GENERAL RULES}

Unlike the component acts of Alberta's pre-PPSA personal property security regime, the PPSA does not merely require registration as a condition precedent to the right to assert a claim against third parties; rather, it imposes what may be an exhaustive priorities scheme. The key priority rules are that:

(a) as between perfected security interests, the security interest which is registered or in respect of which possession occurs first (regardless of whether attachment has occurred) or which is temporarily perfected first has priority;

(b) as between a perfected and an unperfected security interest, the perfected security interest has priority; and

(c) as between unperfected security interests, priority depends on order of attachment (section 25(1)).

Specific rules for certain types of security interests are set out in section 31 , and, pursuant to section 23 , liens for the provision of materials and services in respect of goods obtain priority over security interests in the goods, unless the legislation governing the lien provides otherwise.

\section{B. PURCHASE-MONEY SECURITY INTEREST}

Special priority status is accorded to a class of security interests known as a "purchase-money security interest", which is, in essence, a security interest taken by an unpaid vendor to secure payment of the purchase price. It applies, as well, to lessors of goods in which the lease has a term of more than one year (even where the lease is 
a pure lease and does not secure any obligation), commercial consignors and persons who finance the acquisition of goods; however, it excludes sale-leaseback transactions. Pursuant to section 34(2), a holder of a purchase-money security interest which perfects its interest in collateral, other than inventory, within 15 days (of possession by the debtor of tangible collateral, or of the date on which attachment occurs for intangible collateral) obtains priority over all security interests in the collateral given by the debtor. This preferred status, however, does not extend over extant security interests created by other persons.

In order for a creditor who has taken a purchase-money security interest in inventory to obtain priority over other persons with security interest in the same goods (including those with prior perfected interests), the secured party must have perfected its security interest by the time the debtor (or someone on its behalf) obtains possession of the inventory. As well, the secured party must give notice to other parties who have prior-registered financing statements claiming an interest in the same goods or type of goods. This notice must state that the secured party expects to obtain a purchase-money security interest in the inventory, must describe the inventory by item or kind and must be given before the debtor (or someone on its behalf) obtains possession of the goods.

The super-priority status accorded to purchase-money security interests has one weakness with regard to proceeds from goods in which a purchase-money security interest is held. Section 34(6) of the PPSA reads:

A non-proceeds security interest in accounts given for new value has priority over a purchase-money security interest in the accounts as proceeds of inventory if a financing statement relating to the security interest in the accounts is registered before the purchase-money security interest is perfected or a financing statement relating to it is registered.

Thus, a purchase-money security interest in accounts as proceeds will be defeated by a security interest taken in those accounts, provided that the holder of the security interest in the accounts gave new value. This differs from the general scheme of the PPSA. The rationale for this rule was stated by the Saskatchewan Court of Appeal in TransAmerica Commercial Finance Corporation v. Royal Bank of Canada ${ }^{89}$ as being that an accounts receivable financing should not be jeopardized by the creation of purchase-money inventory financing.

Lenders who obtain purchase-money security interests must be aware of section 86 of the PPSA which amends section 107 of the Land Titles Act.$^{90}$ Section 107 of the Land Titles Act rendered void mortgages, charges or encumbrances of land contained in conditional sales contracts governed by the Conditional Sales Act. ${ }^{91}$ Because the Conditional Sales Act was repealed, section 107 was reworded. Section 107(a) now reads:

A mortgage, charge or encumbrance on land or on any estate or interest therein

(a) contained in a purchase-money security agreement that may be registered under the Personal Property Act . . .

is void to all intents and purposes whatsoever, notwithstanding anything in any Act.

Purchase-money security agreement is defined in section 107(3) to mean:

an agreement that provides for a purchase-money security interest as defined in the Personal Property Security Act.

89. (April 24, 1990), Doc. No. 185 (Sask. C.A.).

90. Supra, note 10.

91. Supra, note 12. 
Thus, a security document in which personal property is charged and which provides funds to a borrower to permit it to acquire property and, in the same document, imposes a charge on real property owned by the borrower is void. Almost all residential and commercial mortgages will be affected by this provision. Until it can be amended, cautious practitioners should ensure that any purchase-money security interests in personal property are granted and governed by a security agreement which is a separate document from the land titles mortgage.

\section{RISK FROM FAILURE TO PERFECT}

Secured parties who do not perfect their interests are at risk. An unperfected security interest is subordinate to the interests of a judgment creditor who seizes the collateral under legal process, a person who seizes the collateral under the Execution Creditors $\mathrm{Act}^{\mathrm{p}}$ or under legal process, or a representative of judgment creditors (section 20(1)(a)). Similarly, the holder of an unperfected security interest cannot raise its rights against a trustee in bankruptcy (section 29(1)(b)) or against a transferee who acquires its interest other than by way of security agreement, who gives value, who is without knowledge of the security interest and who acquires its interest before the security interest is perfected (section 20(1)(c)).

However, perfection does not render a secured party immune from competing claims, as the following examples show:

(a) a person who buys or leases goods from the debtor in the ordinary course of the debtor's business obtains the goods free from perfected and unperfected security interests even if he has knowledge of the security interest, unless he has knowledge that the sale or lease is in breach of the security agreement (section 30(2)). The doctrine of constructive knowledge is largely inapplicable; section 47 provides that registration of a financing statement does not constitute constructive notice of either its existence or its contents. However, this does not make of the common law doctrine of constructive notice completely inapplicable; it may still arise independently of registration; and

(b) If the sale or lease is not made in the ordinary course of the debtor's business and the collateral is equipment which constitutes serial number goods, a buyer or lessee acquires its interest free from a security interest perfected by registration if he lacked knowledge of the security interest and the goods were not described by serial number (section 30(6) and (7).

A buyer or lessee acquires consumer goods free from perfected and unperfected security interests if the goods are not fixtures and have a purchase price, if sold, of less than $\$ 1,000$ or a market value, if leased, of less than $\$ 1,000$; if he or she gave new value for its interest; and if he or she lacked knowledge of the security interest (section 30(3) and (4)).

Temporary perfection is ineffective during the 15 day grace periods against buyers or lessees who give new value for their interests and lack knowledge of the security interest (section 30(5)).

Finally, a holder of money who gave value for it has priority over a perfected security interest in the money. Where the holder did not give value, it is still entitled to priority if it was not aware that the money was subject to a security interest (section 31(1)).

92. R.S.A. 1980 , c. J-1. 


\title{
VI. FLOATING CHARGES - \\ THE GOOD NEWS AND THE BAD NEWS
}

\section{A. THE GOOD NEWS}

\section{History and Nature of Floating Charges}

According to Robert R. Pennington ${ }^{93}$, the floating charge emerged in the late 19th century in order to permit companies to obtain financing by providing security over their stock-in-trade. ${ }^{94}$ The common law recognized mortgages and pledges of personal property, but these forms of security were not appropriate to secure assets which, in the ordinary course of the debtor's business, were bought and sold. Afteracquired goods could become subject to fixed charges only by an act of transfer after the debtor acquired them and goods subject to fixed charges could only be disposed of by the debtor with the express consent of the security-holder. However, on the basis that a contract to charge property once it was acquired would be enforced, equity intervened to permit the mortgage of after-acquired property. ${ }^{95}$ The House of Lords recognized a charge over the entire undertaking of a business in Re Panama, New Zealand and Australian Royal Mail Co. ${ }^{96} \mathrm{However}$, this charge did not interfere with the ability of the company to carry on its business until the business was woundup or the security holder intervened and appointed a receiver (i.e. crystallization). ${ }^{97}$ Floating charges were subordinate to legal fixed charges which were granted after the floating charge was granted, but before crystallization. ${ }^{98}$

The leading pronouncement on the nature of floating charges is that of Lord Justice Buckley in Evans v. Rival Granite Quarries, Ltd.: ${ }^{99}$

\begin{abstract}
A floating security is not a future security; it is a present security, which presently affects all the assets of the company expressed to be included in it. On the other hand, it is not a specific security; the holder cannot affirm that the assets are specifically mortgaged to him. The assets are mortgaged in such a way that the mortgagor can deal with them without the concurrence of the mortgagee. A floating security is not a specific mortgage of the assets, plus a licence to the mortgagor to dispose of them in the course of his business, but is a floating charge applying to every item comprised in the security, but not specifically affecting any item until some event occurs or some act on the part of the mortgagee is done which causes it to crystallize into a fixed security.
\end{abstract}

\section{Fixed Versus Floating Charge Security}

Because floating charges could be defeated by subsequent fixed charges, lenders tended to take fixed charge security wherever possible, and tried to create charges which were fixed in nature but which permitted the debtor to deal with its assets in

93. "The Genesis of the Floating Charge" (1960) 23 Mod. L. Rev. 630 at 630-634.

94. See also G.F. Curtis, "The Theory of the Floating Charge" (1941-42) 4 U.T.L.J. 131.

95. Holroyd v. Marshall (1862), 10 H.L.C. 191.

96. (1870), 5 Ch. App. 318.

97. Re Florence Land and Public Works Co. (1878), 10 Ch. D. 530 at 540-541.

98. Moor v. Anglo-Ihalian Bank (1878), 10 Ch. D. 681 .

99. [1910] 2 K.B. 979 (C.A.) at p. 999. 
the ordinary course of business. Fixed charges worked well for long-term assets, but when inventory and stock-in-trade formed part of the security, the courts would imply a right for the debtor to deal with these assets in the ordinary course of its business. In Dedrick v. Ashdown, ${ }^{100}$ the Supreme Court of Canada implied a right to sell in the ordinary course of business into a chattel mortgage of the debtor's stock-in-trade. Mr. Justice Gwynne rationalized the implied term as follows: ${ }^{101}$

\begin{abstract}
In construing the mortgage before us we must bear in mind that the usual intent and common object of the mortgage of the stock-in-trade of a trader being executed by him is not to effect a winding-up of his business, or as Lindley J. expresses it in Walker v. Clay, "to paralyse his trade", but to enable him to carry on his business in the ordinary course of his trade until default in payment of his debt on the day named in the mortgage for that purpose. . . . Because of the common use of those instruments by traders as security to their creditors while the mortgagor traders continued in possession of the chattels mortgaged, carrying on their trade, disposing of their stock, mortgaged as before, that the Legislature interposed to regulate the instruments as to their contents, their mode of execution and their registration, and ever since they have become a common assurance in use between traders, and recognized by the Legislature for the express purpose of enabling the trader debtor to continue carrying on his business, disposing of his stock in trade in the ordinary course of his business until default, while vesting the property in the stock-in-trade in the mortgage creditor, giving him a security in preference to other creditors.
\end{abstract}

The nature of the charge under consideration in Dedrick v. Ashdown, although it was not addressed in detail in the case, seems to have been a fixed charge over inventory with a right for the mortgagor to dispose of inventory in the ordinary course of its business. Modern courts, however, have indicated a resistance in recognizing fixed charges with a licence, whether express or implicit, to sell in the ordinary course of business, finding rather that such charges are floating (see The Queen in Right of British Columbia v. Federal Business Development Bank ${ }^{102}$ and Bank of Montreal v. Titan Landco Inc. ${ }^{103}$ ). The basis for this refusal is that there must be a new act or conveyance ${ }^{104}$ in order for after-acquired property to become subject to a fixed charge, and that assets subject to a fixed charge cannot be sold without a specific release by the secured party.

The Alberta Court of Appeal in Redalta Building Products Ltd. v. Province of Alberta Treasury Branches, ${ }^{105}$ recognized a fixed security interest where the nature of the asset and the debtor's required dealings would have led one to expect a different holding. In Bank of Montreal v. Titan Landco Inc. ${ }^{106}$ a right to dispose of the charged property in the ordinary course of the mortgagor's business was read into a fixed charge over inventory, according to the principle enunciated by Dedrick v. Ashdown. ${ }^{107}$ The charge was then found to be floating rather than fixed. This type of reasoning might be rejected in Alberta courts. In Redalta, Mr. Justice Kerans suggests that if parties to a security agreement are unsuccessful in creating the fixed charge which they intend to create, the courts will not convert the charge into a floating charge; the fact that the debtor agreed to a charge which paralyses his trade does not entitle the courts to rewrite the parties' contract.

100. (1887), 15 S.C.R. 227.

101. Ibid., pp. 243-245.

102. (1987), 43 D.L.R. (4th) 188 (B.C.C.A.).

103. (1989), 41 B.L.R. 14 (B.C.S.C.).

104. Supra, note 100 at 216 citing Gough's Company Charges (1978).

105. (November 30, 1984) 15572 (Alta. C.A.).

106. Supra, note 103.

107. Supra, note 100. 
The conclusion that can be drawn from the foregoing is that lenders appear to have a real preference for fixed security and the priority against competing creditors that it confers. Lenders attempt to obtain security of that status even on assets which are of a fluctuating nature. The courts, on the other hand, have a tendency to examine the commercial reality of the situation and are often disinclined to confer the status of fixed security where the nature of the asset or its permitted uses are contrary to that conclusion. In fact, the courts have gone so far as to suggest that a lender might find itself unsecured where it unsuccessfully attempts to engineer a fixed charge interest in such situations. Lenders then face the uncertainty under the current law of not in fact having the interest and hence the security position, including the priority, which they intended to procure. Security over fluctuating equipment, contracts and production are commonly contained in the charging clauses in oil and gas trust deeds and debentures. Accordingly, the thorny issues raised by the cases discussed above confront oil patch lenders.

\section{The PPSA and Floating Charges}

When the Ontario PPSA was first introduced in 1976, it was silent as to its application to floating charges. However, early cases established its applicability. In Royal Bank of Canada v. Inmont Canada Ltd. ${ }^{108}$ Clements Co. Ct. J. found the PPSA to govern priorities between two competing assignments of accounts, which he treated as being floating charges, without considering whether the charge was fixed or floating.

The Alberta PPSA contains specific references to floating charges. Section 3(1)(b), which lists specific types of pre-PPSA security interests included within the scope of the PPSA, refers to floating charges, and section 12(1) states that the rules for attachment of security interests apply to floating charges.

Applying a PPSA analysis to floating charges, one would conclude that the PPSA has eliminated one of the key differences between fixed and floating security, that being that floating charges are defeated by subsequent fixed charges. A floating charge is a security interest within the meaning of the PPSA and, according to section 12(1), it attaches when value is given by the secured party, the debtor has rights in the collateral (see First City Capital v. Arthur Andersen Inc. ${ }^{109}$ ) and the security interest is enforceable within the meaning of section 19 (i.e. the secured party has taken possession of the collateral or a security agreement containing a sufficient description of the collateral has been executed). The mere fact that a charge is floating in nature has consistently been found not to imply deferred attachment (see Royal Bank v. G.M. Homes Inc. " ${ }^{10}$ and Roynat Inc. v. United Rescue Services Ltd. "'). According to section 25 , a secured party can register a financing statement to perfect its interest. The security interest in all of the assets owned by the debtor at the time of registration of the financing statement (assuming that value has been given by the lender) will have attached and been perfected, and it will attach to property subsequently acquired by the debtor. As the security interest has been perfected and the order in which

108. (1980), 1 P.P.S.A.C. 197 (Ont. Cty. Ct.).

109. (1984), 4 P.P.S.A.C. 74 (Ont. S.C.).

110. (1984), 4 P.P.S.A.C. 116 (Sask. C.A.).

111. (1982), 2 P.P.S.A.C. 49 (Man. C.A.). 
attachment and perfection occur is immaterial (section 19), the lender will have a perfected security interest in all of the assets of the debtor at any given time.

Several sections of the PPSA support this type of analysis. Section 13(1) provides that a security interest in after-acquired property attaches according to section 12 without any specific appropriation of the property. Section 34(3) permits a purchasemoney security-interest, which has priority over prior security interests in the same collateral, to be taken in respect of inventory. Previously, it was thought that inventory could only be secured by way of floating charge as the nature of inventory requires that it be capable of being sold in the ordinary course of business (see The Queen in Right of British Columbia v. Federal Business Development Bank ${ }^{112}$ ) and that any charge over inventory must permit the debtor to dispose of the inventory in the ordinary course of its business (Dedrick v. Ashdown ${ }^{133}$ ). By giving a charge over assets which constitute inventory priority over pre-existing charges on those assets, the PPSA has conferred on floating charges the status previously accorded only to fixed charges.

Further, one of the ways by which the holder of a floating charge could protect itself from subsequent fixed charges was to insert a negative covenant in the security agreement which prohibited the debtor from granting charges which would rank in priority to the floating charge (see Lloyds Bank of Canada v. Lumberton Mills ${ }^{114}$ ). Section 33 of the PPSA has nullified this protection, permitting a debtor to transfer collateral, notwithstanding a prohibition against this in the security agreements. The Amendment Act defines "transfer" to include the creation of a security interest. While both versions of section 31 state that the secured party's rights under the security agreement are not prejudiced (e.g. the right to treat the transfer as an event of default), the inclusion of such a section suggests that its protection is not necessary, that a lender's priority position is determined by perfection and a prohibition against charges purporting to rank in priority is redundant, except for the purposes of defining events of default.

\section{PPSA CASE LAW AND FLOATING CHARGES}

Unfortunately, courts have had difficulty in severing PPSA security interests and floating charges from the historical trappings which developed alongside floating charges. This trend is particularly evident in Ontario. In Re Urman, "is the Ontario Court of Appeal considered a priority dispute between the assignee of a mortgage broker's book debts and assignees of mortgages. While the assignment of book debts (which was floating in nature) attached to each book debt as it came into existence and the assignee had perfected its interest before the interests of the assignees of the mortgages arose, the Court stated that the floating charge had not crystallized (presumably by the sending of notices to the broker's account debtors) until after the assignees of the mortgages acquired their interests. The floating charge assignment was, therefore, subordinate to the legal assignments, regardless of its prior attachment and perfection. This finding completely undermines the attachment and perfec-

112. Supra, note 102.

113. Supra, note 100.

114. (1988), 32 B.C.L.R. (2d) 67 (C.A.).

115. Supra, note 48 at 258. 
tion concept, reducing them to events which must occur in order for the holder to assert its rights but which are completely irrelevant to the determination of priorities. Nothing in the PPSA supports this importation of common law doctrine.

In a different context (the relevance of knowledge of prior, unperfected security interests), McLellan J. of the Saskatchewan Court of Queen's Bench made the following comments concerning maintaining the integrity of the PPSA: ${ }^{116}$

[Section 35] establishes a code for determining the priority between conflicting perfected security interests in the same collateral. The concept of perfected security interests is unknown in either common law or equity. Perfection is a creature of the PPSA.

... It was the intention of the Legislature to provide a method whereby commercial transactions can be concluded with relative ease and certainty. The scheme is quite simple. A secured party must perfect his security or he runs the risk of losing out to more diligent lenders.

These comments on the nature of priorities and the PPSA support the thesis that the PPSA alone governs priority issues concerning security interests to which it applies.

However, the PPSA has not rendered irrelevant the differences between fixed and floating charges. Re National Bank of Canada et al. v. McArthur et al. ${ }^{117}$ affirming National Bank of Canada v. Director of Employment Standards, ${ }^{118}$ concerned a priorities dispute between the holder of a floating charge debenture and a general security agreement which arguably created a fixed charge and employees of a bankrupt company who claimed pursuant to a statutory lien for accrued vacation pay. Because section 3(1)(a) of the Ontario PPSA excluded liens created by statute from the PPSA's application, the priority rules contained in the PPSA were of no assistance and common law priorities were applied. The majority of the Divisional Court resolved the issue in favour of the employee's lien without characterizing the security interest as fixed or floating, but Mr. Justice Eberle, in dissent, found the security interest to be a floating charge.

In both Re National Bank and Armstrong v. Coopers \& Lybrand Ltd. ${ }^{19}$ (a case in which section 178 security was found to be a floating charge), the competing claims were by employees for accrued vacation pay pursuant to statutory liens and can be distinguished on this basis. It may be impossible to avoid pre-PPSA characterizations of security interests as fixed or floating charges to determine priorities when the PPSA priority scheme does not apply, but this characterization should be irrelevant as between PPSA security interests.

\section{Conclusion}

There is no doubt that jurisprudence considering floating charges under the PPSA could be more consistent. The good news is that departures from the Act are becoming exceptions and we can expect that, with respect to assets falling within the purview of the Act, the PPSA will be found to provide oil and gas lenders with the priority of fixed charge security even where the assets are of a fluctuating nature. Oil and gas lenders can, therefore, avoid the shortcomings of the floating charge and the uncertainties which result when attempts are made to fix security interests in assets that are fluctuating by nature and use.

116. Supra, note 69 at 55 .

117. (1986), 53 O.R. (2d) 385 (Div. Ct.).

118. (1983), 3 P.P.S.A.C. 119.

119. (1987), 61 O.R. (2d) 129 (C.A.). 


\section{B. THE BAD NEWS - FLOATING CHARGES OVER REAL PROPERTY}

Division 2 of Part 7 of the Business Corporations Act ${ }^{120}$ of Alberta will be repealed by the Act. Division 2 provides a registration system for mortgages, which include floating charges, of property situated in Alberta created by corporations. It provides, with certain exceptions, that unless such mortgages, including floating charges, are registered as contemplated by that Act, the security is void against a creditor of the corporation and any subsequent bona fide purchaser or mortgagee for value. The Act provides that a mortgage takes effect against such persons only from registration. Legal opinions in secured transactions involving corporate floating charges are rendered on the basis of the provisions of Division 2, which applies to all floating charges granted in the property or undertaking of a corporation.

As discussed above, floating charges are specifically referenced in section 3(1)(b) of the PPSA as being within the ambit of the Act. Section 4 states, however, that the Act does not apply to the creation or transfer of an interest in land.

Accordingly, the result is that the PPSA does not apply to floating charges over real property. Various provisions of the Act support the foregoing conclusion; in fact, the entire purpose and scope of the Act is to facilitate the securing of interests in personal property. This conclusion is made apparent by examining a few of the Act's key provisions: sections 10 (dealing with enforceability), 12 (dealing with attachment) and 19 (dealing with perfection) all reflect this conclusion. Central to the meaning of each of these key sections are the definitions "collateral" and "security interest". "Collateral" is defined to mean "personal property that is subject to a security interest". By definition, "security interests" can be interests in goods, chattel paper, a security, a document of title, an instrument, money, an account, a commercial consignment, or the interest of a lessor under a lease of more than one year. Section 4 of the Act excludes interests in land, including leases, and all of the other interests referred to above are personal. Accordingly, the Act will only assist the delivery of enforceability and priority opinions respecting floating charges on personal property.

Floating charge debentures granted by oil and gas companies typically pertain to the real and personal property of the corporation, and may be expressly limited to a corporation's real property. As well, notwithstanding their legal shortcomings, floating charges have recently become very popular among lenders. The popularity of the floating charge in part appears to have been spurred by the recent tough times in the oil patch. These conditions have caused many lenders and borrowers to be very costconscious. Floating charges can be taken for only a fraction of the cost associated with fixed security. Also, many of the debt workouts and realizations have shown that the remedies granted by such charges can be very effective. As a result of the proclamation of the PPSA and the repeal of Part 7 of the Business Corporations $A c t,{ }^{121}$ priority issues respecting floating charges on real property will have to be answered by resorting to common law principles, while the PPSA will govern the issue to the extent that the debenture pertains to personal property. A creditor holding a floating charge over all of the assets of a corporation could find itself behind a nonPPSA perfected prior existing floating charge granted over the same assets insofar as

120. Supra, note 8 .

121. Ibid. 
the charge pertains to mineral leases but ahead of the prior creditor with respect to personal property.

As a result of the foregoing, there will not be a demise of the floating charge debenture in oil and gas financings in Alberta. The general security agreement popular in PPSA jurisdictions offers a substitute for the floating charge to cover personal property, but there is no concept or body of law that allows a similar type of interest in real property other than the common law's floating charge. Although the floating charge over real property will continue, there is no applicable registration system so that solicitors will not be able to render priority opinions based upon a statutory registration system. Indeed, this situation places considerable doubt on the effectiveness of the instrument against third parties. This will no doubt undermine the usefulness of this otherwise flexible, convenient and cost-effective instrument.

\section{FIXTURES AND ACCESSIONS}

Two sections of the PPSA are of particular importance to lenders who take security on oil and gas equipment and facilities: section 36, concerning fixtures, and section 38 , concerning accessions. It is possible for a lender to lose its priority position regarding chattels which become so affixed to the realty on which they are located that they lose their character as personalty, becoming part of the realty (fixtures), or where chattels, which form part of the security, are attached to another chattel, becoming part of it (accessions). The PPSA attempts to impose certainty in the area of priorities to fixtures and accessions.

\section{A. FIXTURES}

The determination of whether an article has become so attached to land that it loses its independent identity depends on the particular facts which establish the degree and object of annexation. ${ }^{122}$ Numerous principles have arisen to aid in the determination, but Patterson J.A. in Keefer v. Merrill' ${ }^{123}$ noted:

I find it impossible to follow the discussion of the question, as it has arisen in a very large number of cases, whether certain articles are or are not fixtures, with any confidence in my ability to discover a principle that will satisfactorily apply to all cases. The distinctions made are sometimes so fine as not to be easily perceptible, and I am inclined to think that the task to bring all the decisions into harmony would be a hopeless one.

The leading Canadian case on when an article becomes a fixture is Stack v. Eaton, ${ }^{124}$ in which Chief Justice Meredith summarizes the established principles:

(a) articles not otherwise attached to the land than by their own weight are not to be considered as part of the land, unless the circumstances are such as shew that they were intended to be part of the land;

(b) articles affixed to the land even slightly are to be considered part of the land unless the circumstances are such as to shew that they were intended to continue chattels;

(c) the circumstances necessary to be shewn to alter the prima facie character of the articles are circumstances which shew the degree of annexation and object of such annexation, which are patent to all to see;

(d) the intention of the person affixing the article to the soil is material only so far as it can be presumed from the degree and object of the annexation; and

122. Holland v. Hodgson (1872), L.R. 7 C.P. 328, [1861-73] All E.R. Rep. 237.

123. (1881), 6 O.A.R. 121 at 136.

124. (1902), 4 O.L.R. 335 at 338 (Div. Ct.). 
(e) even in the case of tenants' fixtures put in for the purposes of trade, they form part of the freehold, with the right, however, to the tenant, as between him and his landlord, to bring them back to the state of chattels again by severing them from the soil, and that they pass by a conveyance of the land as part of it, subject to this right of the tenant.

Intention, in fixture cases, is objective, rather than subjective; it is presumed from the degree and object of annexation. Clauses in agreements which state that articles are to become fixtures, or that, notwithstanding extensive annexation, they are to retain their status of personalty have been enforced (see Clark v. Royal Bank of Canada ${ }^{25}$ and Assiniboine Credit Union Limited v. Canadian Imperial Bank of Commerce ${ }^{126}$ ). These clauses may only be operative as between the parties thereto. ${ }^{127}$

Other tests employed by the courts are essentially restatements or expansions of these five principles. For example, if the chattel is affixes to the land to facilitate its own usefulness, it is likely a removable fixture, while if the annexation is for the benefit of the land, it is likely a fixture, even where the degree of annexation, in and of itself, is not sufficient to connote the change to realty (see Haggert v. Town of Brampton; ${ }^{128}$ Re Davis; ${ }^{129}$ Publishers Holdings Ltd. v. Industrial Development Bank. ${ }^{130}$ Or, the amount of damage which removal would case may be considered (see, for example, Liscombe Falls Gold Mining Co. v. Bishop. ${ }^{131}$ If removal would cause extensive damage to the realty, the article is a fixture, while, if removal would cause little or no damage to the realty, it is likely a removable fixture. ${ }^{132}$

At common law, a purchaser or mortgagee of land without notice of an interest claimed in a chattel or removable fixture is entitled to articles attached to the land. ${ }^{133}$ This carried through into the statutory personal property regime in place before the PPSA. In Plaza Equities Limited v. Bank of Nova Scotia, ${ }^{134}$ a mobile home had been sold pursuant to a conditional sales contract but the vendor did not register a financial interest statement in respect of its interest pursuant to section 2 of the Conditional Sales Act. ${ }^{135}$ The vendor's interest was defeated by a subsequent land mortgagee without notice and the vendor lost the right to have the mortgagee pay out the amount owing under the conditional sales agreement.

Articles which have become fixtures may become personalty on being severed from the land. A special class of removable fixtures (called trade fixtures) is recognized: a lessee was entitled to remove property which was affixed to land in furtherance of its trade. ${ }^{136}$

125. (1987), 7 P.P.S.A.C. 214 (Sask. Q.B.).

126. [1984] 5 W.W.R. 251 (Man. C.A.).

127. Anger and Honsberger, The Canadian Law of Real Property, 2nd ed. (Aurora Ontario: Canada Law Book Inc., 1985) at 1056 to 1058.

128. (1897), 28 S.C.R. 174.

129. [1954] O.W.N. 187.

130. [1974] 4 W.W.R. 440.

131. (1905), 35 S.C.R. 543.

132. Hobson v. Gorringe, [1897] I Ch. 182, [1895-99] All E.R. Rep. 1231 (C.A.).

133. See Hobson v. Gorringe, [1897] I Ch. 182, [1895-9] All E.R. Rep. 1231 (C.A.).

134. (1978), 84 D.L.R. (3d) 609, [1978] 3 W.W.R. 385 (Alta. S.C.T.D.)

135. Supra, note 12.

136. Bain v. Brand (1876), 1 App. Cas. 762. 


\section{B. OIL AND GAS ASSETS}

Security taken by lenders in oil and gas assets will often include interests in the debtor's equipment. For drilling companies, the major assets will be drilling rigs, which because of their mobile nature, are unlikely to have a sufficient degree of annexation to become fixtures. While it is difficult to rely on prior case law in determining whether an asset is a fixture, it is interesting to note that the English Court of Appeal in Burnside v. Marcus ${ }^{137}$ concluded that an engine for drilling for oil was not a fixture. As well, a derrick erected in a quarry has been found to be a chattel. ${ }^{138}$ In the United States, well casings, derricks and engines have been found to be trade fixtures. ${ }^{139}$ While it is impossible to make definitive statements, it is likely that drilling equipment on leased lands will not become fixtures or, if they do become fixtures, they are removable fixtures because a standard lease permits the lessee to remove its machinery, equipment, structures, pipelines, casings and materials from the lands on termination of the lease. ${ }^{140}$

Facilities pose a greater problem. Major gas plants which have foundations constructed into the earth will usually constitute fixtures. On the other hand, boosters and compressors may or may not be fixtures, depending on their portability. As their is a surprising dearth of judicial consideration on whether oil and gas facilities are fixtures, one can look to other industries and analogize, but each asset will ultimately have to be considered independently, based on the particular facts surrounding it. Machinery which was necessary to the operation of a mill was found to be a fixture, even though it was not affixed, but merely rested on its own weight. This was due to the fact that it was placed in the mill as component parts, albeit unattached. ${ }^{141}$ Underground tanks and pumps for gasoline storage have also been found to be fixtures. ${ }^{142}$ However, a stamp mill which rested by its own weight or was attached by bolts was a chattel or removable trade fixture. ${ }^{143}$ In the United States, plants and equipment located within them have been found to be fixtures: ${ }^{144}$

The trial court correctly held in this case that the equipment was annexed and a part of the plant necessary

for the production of oil under the leases and that respondents were, therefore, sellers of real property alone. Some of the minor items of equipment were not attached to the realty, but they were used with and essential to other equipment attached to the realty with which they constituted a unit and were, therefore, constructively annexed (Pajaro Valley Bank v. County of Santa Cruz 207 Cal. App. 2d 621). It accords with experience and common sense to hold, as we do, that the equipment in place necessary to operate an oil lease partakes of the nature of the lease as real property in the situation disclosed by the record in the case.

This type of analysis is similar to that employed in Dickson v. Hunter. ${ }^{145}$ If it is applied in Canada, all equipment in a gas plant found to be a fixture would be part of the fixture as well.

137. (1867), 17 U.C.C.P. 430.

138. Lahey v. Queenston Quarry Co. Ldd. (1916), 11 O.W.N. 18 (H.C.); affirmed at 120 (S.C.A.D.).

139. W.L. Summers, The Law of Oil and Gas, (Kansas City, Mo: Vernon Law Book Company, 1958) at 453.

140. Ballem, The Oil and Gas Lease in Canada, 2nd ed. (Toronto: University of Toronto Press, 1985).

141. Dickson v. Hunter (1881), 29 GR. 73.

142. Gordon v. Fraser (1918), 43 O.L.R. 31 (H.C.).

143. Liscombe Falls Gold Mining Co. v. Bishop (1905), 35 S.C.R. 539 at 541.

144. McGreevy v. Constitution Life Insurance Company (1965), 47 Cal. Reptr. 711 (Cal. Dist. C.A.).

145. Supra, note 141 . 
Because of the uncertainty in characterizing many oil and gas assets as fixtures or personalty, lenders should consider maximizing their protection by complying with both the real property and personal property security regimes.

\section{THE PPSA AND FIXTURES}

The uncertainties of characterizing assets as fixtures are carried through into the PPSA; "fixture" is not defined, other than to exclude "building materials" from its scope. "Building materials" is defined in the Amendment Act as:

materials that are incorporated into a building and includes goods attached to a building so that their removal

(i) would necessarily involve the dislocation or destruction of some other part of the building and cause substantial damage to the building, apart from the loss of value of the building resulting from the removal, or

(ii) would result in weakening the structure of the building or exposing the building to weather damage or deterioration,

but does not include heating, air conditioning or conveyancing devices machinery installed in a building or on land for use in carrying on an activity inside the building or on the land (emphasis added);

While this latter exclusion would cover equipment located in major facilities so that such equipment is not within the definition of "building materials", these pieces of equipment may still be fixtures and the common law tests must be applied. Michael E. Burke suggests that the PPSA has a tripartite classification: building materials, which have become realty and which are governed exclusively by land law; fixtures, which at law have become realty but which are still sufficiently associated with personal property to merit their inclusion under the PPSA; and pure personalty, which includes chattels which are not sufficiently affixed to realty to become realty. ${ }^{146} \mathrm{Thus}$, under the PPSA, the analysis is not the common law determination of fixtures as opposed to realty, but requires consideration of these categories.

Two sections of the PPSA concern fixtures. Section 49 permits (but does not mandate) a lender whose security includes fixtures to register a notice at the land titles office for the district in which the fixture is located (section 49(2)), and on receipt of this notice, the registrar of the land titles office endorses a memorandum of the notice on the certificate of title for the lands to which the fixture is annexed.

More controversial than section 49 is section 36 which purports to impose a priorities regime on persons who acquire interests in goods which are or which become fixtures. The first matter of concern to oil and gas lenders is subsection (1) which states that section 36 applies only to land for which a certificate of title has been issued under the Land Titles Act. ${ }^{147}$ When dealing with unpatented lands, priorities will depend on common law principles.

According to section 36(2), the general rule is that when a security interest attaches before or at the time that the goods to which it applies become fixtures, the holder of the security interest has priority over persons claiming an interest in land. However, this rule is subject to section 30 and to the rest of section 36 . Two subsections in section 30 are relevant in oil and gas transactions. Subsection (6) applies to equipment which is "serial number goods" which is defined in the Regulations as motor vehi-

146. M.E. Burke, "Fixture Financing Under the PPSA: The On-going Conflict Between Realty and Fixture-Secured Interests" (1987) 24 Osgoode Hall L.J. 547 at 553-554.

147. Supra, note 10. 
cles, trailers, mobile homes, aircraft airframes, aircraft engines, aircraft propellers and boat outboard motors. A buyer or lessee of these goods is not bound by a security interest which has been perfected by registration if the buyer or lessee is without knowledge of the security interest and the goods are not described by serial number. Each of these conditions precedent requires discussion. Firstly, section 47 provides the registration of a financing statement is not constructive notice of the registration or its contents; a buyer or lessee would have to have actual notice of the security interest in the particular piece of equipment. Secondly, the regulations require serial number goods which are consumer goods to be described by serial number while serial number goods which are equipment may, but need not, be described by serial number. If a lender describes the collateral which is serial number goods by serial number, it can preclude application of this subsection.

Section 30(2) will also be of particular importance to lenders who finance oil and gas equipment dealers. If a debtor sells or leases goods in the ordinary course of its business, the buyer or lessee defeats a perfected or unperfected security interest granted by the debtor regardless of whether the buyer or lessee has knowledge of the security interest, unless the buyer or lessee knows the sale or lease constitutes a breach of the debtor's security agreement.

There is one major exception contained in section 36 . The holder of the security interest whose interest attaches before the goods become fixtures loses priority to persons who acquire interests in land after the goods become fixtures, mortgagees who have registered their interests and who make an advance after the goods become fixtures, but only to the extent of the advance, and mortgagees who obtain vesting orders or orders confirming sale in a foreclosure action. However, these persons must be without fraud and their interests must be acquired before the security interest is registered against title pursuant to section 49.

There is no case law yet concerning the meaning of the phrase "without fraud" but there is no reason to assume that it has a different definition than that which evolved for "land titles fraud" as discussed in Holt Renfrew \& Co. Ltd. v. Henry Singer Ltd. ${ }^{148}$ Something more than mere knowledge of the prior unregistered interest is needed. The Ontario PPSA uses the phrase "without actual notice" and Manitoba uses "without notice" (s. 36(4)), but Saskatchewan uses "without fraud".

Section 36(3) causes an interesting priorities problem, as illustrated by the Ontario case of G.M.S. Securities \& Appraisals Ltd. v. Rich-Wood Kitchens Ltd. ${ }^{149}$ There, Rich-Wood held a PPSA security interest in kitchen cabinets which had attached and was perfected under the PPSA. The cabinets were installed in a house. National Trust held a first mortgage on the property and, after Rich-Wood's security interest attached, G.M.S. became the second mortgagee and made an advance. Pursuant to the equivalent of section 36(2), Rich-Wood had priority over National Trust since National Trust had not made any advances after Rich-Wood's security interest attached. National Trust, as first mortgagee, had priority over G.M.S., the second mortgagee, according to land titles law. G.M.S. had priority over Rich-Wood pursuant to the equivalent of section 36(3) since G.M.S. had made advances after the cabinets became fixtures and had no knowledge of Rich-Wood's security interest which had not been endorsed on title pursuant to the equivalent of section 49.

148. (1982), 20 Alta. L.R. (2d) 7, [1982] 4 W.W.R. 481,135 D.L.R. (3d) 391,37 A.R. 90 (C.A.); leave to appeal to the Supreme Court of Canada refused (1983), 22 Alta. L.R. (2d) XXXvi.

149. (1989), 9 P.P.S.A.C. 153 (Ont. S.C.). 
To resolve this circle of priorities, McDermid L.J.S.C. applied a common sense approach. He ordered National Trust to pay Rich-Wood the balance owing for the cabinets since National Trust took its security on property without cabinets but the property which it sold had the benefit of the cabinets. However, since G.M.S. was entitled to the balance of the proceeds of sale once National Trust had been paid in full, National Trust could not use the proceeds of sale to pay Rich-Wood. This solution gave each party what it was entitled to, but quaere what would happen when the proceeds of sale were not sufficient to pay the first mortgagee in full; the second mortgagee who made advances after the goods became fixtures would not have its priority recognized. Perhaps, to give effect to second mortgagee's priority over the PPSA security holder, the PPSA security holder would be required to pay the money it receives from the first mortgagee to the second mortgagee.

McDermid L.J.S.C. rejected the argument that because Rich-Wood failed to do everything which it could have done to protect its security interest (i.e., registering a notice of its interest at the land titles office), it should lose the benefit of the PPSA and be third in line under the land titles scheme. This rejection is important because this would have provided an easy solution to the conundrum, but it would have penalized Rich-Wood for failing to do something which it was permitted, and not required, to do. The Ontario PPSA fixtures provision requires only that the subsequent mortgagee be without actual notice of the PPSA security interest; there is no requirement that its interest arise before filing a notice at the land titles office (s. 36(3)). The inclusion in the Alberta PPSA of this requirement is not, however, significant since once the notice is endorsed on title, a subsequent mortgagee will acquire notice of it upon registering its mortgage and obtaining a certificate of title.

Where a lender acquires a security interest in goods after they become fixtures, its interest is subordinate to the interests of persons who hold an interest in the lands at the time the goods become fixtures and who have not consented to the security interest, disclaimed an interest in the goods (see Royal Bank of Canada v. Farm Credit Corporation ${ }^{150}$ ) or entered into an agreement entitling someone to remove the goods, or is not otherwise precluded from preventing the debtor from removing the goods. Persons who acquire interests in the land after the goods become fixtures, without fraud and before a notice is registered pursuant to section 49 also obtain priority (section 36(4)).

In order to protect themselves, lenders who are taking security on assets which may become fixtures should do the following:

(a) obtain the consent of persons with registered prior interests in the land;

(b) register a notice pursuant to section $\mathbf{4 9}$ to terminate the subsequent land interests which can obtain priority over the security interest; and

(c) review the lease by which the debtor holds its interest in the property. The lease may entitle the lessee to remove all equipment on termination of the lease. In Assiniboine Credit Union v. Canadian Imperial Bank of Commerce ${ }^{151}$ and Clark v. Royal Bank of Canada, ${ }^{152}$ the courts held that where a lease entitles the lessee to remove dwellings, at the end of the lease, the dwelling is personalty, notwithstanding that their removal will cause extensive damage.

150. (1988), 8 P.P.S.A.C. 208 (Ont. S.C.).

151. (1984), 4 P.P.S.A.C. 96 (Man. C.A.).

152. (1987), 7 P.P.S.A.C. 214 (Sask. Q.B.). 
On this reasoning, equipment which the lessee is permitted or required to remove may not be capable of becoming fixtures.

With the exception of G.M.S. Securities, ${ }^{153}$ the reported cases involving PPSA fixture-security interests relate to the questions of whether goods are building materials or fixtures (see Manning v. Furnasman Heating Ltd. ; $^{\text {s4 }}$ Charles A. Hare Ltd. v. Payn; ${ }^{155}$ and Rockett Lumber and Building Supplies Limited v. Papageorgiou ${ }^{156}$ ) or whether goods are sufficiently affixed to land to be fixtures (see Cormier v. Federal Business Development Bank; ${ }^{157}$ Royal Bank of Canada v. Farm Credit Corporation; ${ }^{158}$ Dolan v. Bank of Montreal; ${ }^{159}$ Assiniboine Credit Union Ltd. v. Canadian Imperial Bank of Commerce; ${ }^{160}$ and Clark v. Royal Bank of Canada $\left.{ }^{161}\right)$.

\section{CONCLUSION}

The PPSA has altered fixture law to explicitly provide for the priority of a chattel security holder whose security interest attaches before or at the time that the chattel becomes a fixture. It also clarifies the law concerning agreements permitting chattels to be removed (section 36(4)(iii)). However, the priorities regime may still be problematic and prudent lenders will register their security interests in goods which may become fixtures under section 49 as well as registering the security interest under section 25 .

\section{E. ACCESSIONS}

Section 38, governing security interests in goods which become accessions to other goods, is very similar to section 36 . The only substantive difference is that in section 36(3) and (4), the pre-requisite to obtaining priority is being "without fraud", while pursuant to section 38(3) and (4), a person claiming an interest in the whole, need only be "without knowledge of the security interest in the accession". This distinction is understandable in light of the land titles system and the abolition of the prior notice concept.

To protect its security position, a lender need only perfect its security interest in accordance with the PPSA; however, a secured party who perfects its security interest simultaneously with its attachments is theoretically exposed to any claims from persons with security interests in the whole chattel. Section 47 provides that registration of a financing statement does not constitute constructive notice or knowledge of its existence or its contents to third parties. A secured party who perfects its interest in goods which become an accession by registration may, therefore, lose priority to a person with a security interest in the whole if that person was not aware of the

153. Supra, note 149.

154. (1985), 5 P.P.S.A.C. 67 (Man. C.A.).

155. (1982), 2 P.P.S.A.C. 93 (Ont. S.C.).

156. (1979), 30 C.B.R. 183 (Ont. Co. Ct.).

157. (1983), 3 P.P.S.A.C. 161 (Ont. Co. Ct.).

158. (1988), 8 P.P.S.A.C. 208 (Ont. S.C.).

159. (1985), 5 P.P.S.A.C. 196 (Sask. C.A.).

160. Supra, note 151.

161. Supra, note 152. 
accession, and perhaps even if the person does not perform any searches to ascertain the existence of security interests in portions of the whole. It is unclear what the courts will do in situations of wilful blindness. Section 47 does not preclude the application of common law constructive notice; it merely states that registration is not constructive notice. The British Columbia Court of Appeal in Lloyds Bank of Canada v. Lumberton Mills Ltd. ${ }^{162}$ held that a creditor could not obtain priority by failing to search to ascertain competing interests, albeit, not in the context of the PPSA and section 47.

\section{INTERACTION BETWEEN THE PPSA AND BANK ACT SECURITY}

\section{A. BANK ACT SECURITY}

Section 178 of the Bank $A c t^{163}$ (and its predecessors) and its interaction with the PPSA has been the subject of extensive judicial and academic commentary, while commentary on section 177 generally, and its interaction with provincial property schemes, is virtually non-existent. However, two substantial issues arise in oil and gas financings concerning the overlap between federally-regulated and provinciallyregulated security interests which may bring section 177 before the Courts.

Section 177 (1) empowers banks to lend money on security consisting of hydrocarbons and minerals, as follows:

(1) Loans on hydrocarbons and minerals - A bank may lend money and make advances on the security of any or all of the following:

(a) hydrocarbons or minerals in, under or on the ground, in place or in storage,

(b) the rights, licenses or permits of any person to obtain and remove any such hydrocarbons or minerals and to enter on, occupy and use lands from or on which any of such hydrocarbons or minerals are or may be extracted, mined or produced,

(c) the estate or interest of any person in or to any such hydrocarbons or minerals, rights, licenses, permits and lands whether the estate or interest is entire or partial, and

(d) the equipment and casing used or to be used in extracting, mining or producing or seeking to extract, mine or produce, and storing any such, hydrocarbons or minerals.

or of any rights or interest in or to any of the foregoing whether the security be taken from the borrower or from the guarantor of the liability of the borrower or from any other person.

Some of the security described above is in real property (e.g. the right to enter on and use lands from which hydrocarbons may be extracted), and some security is in personal property (e.g. equipment and severed hydrocarbons).

In a typical oil and gas financing, the lender will take both section 177 security and security interests regulated under the provincial personal property schemes. Two substantiative issues arise. First, can a bank gain additional rights and benefits by registering a PPSA security interest when it takes section 177 security? Note that in Saskatchewan, section 177 security is routinely registered under the Saskatchewan 
PPSA. Secondly, how will the conflicting priority provisions of the two regimes be resolved, and how can lenders minimize the risk of prior security interests under the other regime?

\section{B. REGISTRATION UNDER THE PPSA}

Pursuant to section 177, a bank is entitled to lend money and make advances by taking security in various types of personal property. Hydrocarbons and equipment, the primary forms of personal property encompassed by section 177 security, are goods within the meaning of the PPSA which secure the repayment of the underlying loan. Since a PPSA security interest does not have to fit within a common law or equitable pigeon-hole, a statutory creation like section 177 security which meets these criteria fulfils the definition of "security interest" because it creates an interest in personal property which secures performance of an obligation.

Unlike the Ontario, Manitoba and Saskatchewan PPSAs, the Alberta Act specifically provides that it does not apply to Bank Act security agreements. Section 4(b) states:

4. Except as otherwise provided in this Act, this Act does not apply to the following:

(b) a security agreement governed by an Act of the Parliament of Canada that deals with rights of parties to the agreement or the rights of third parties affected by a security interest created by the agreement, and any agreement governed by Division B of Part V of the Bank Act.

Section 177 is part of Division B of Part V of the Bank Act (the "Division").

The meaning of this exclusion is unclear. Does it mean that a bank which holds section 177 security cannot register its security interest under the PPSA, thereby acquiring the benefits and burdens of registration under the Act, or does it merely reiterate the principle enunciated by the Supreme Court of Canada in Bank of Montreal $\mathrm{v}$. Hall ${ }^{164}$ that provincial legislation cannot impose additional requirements on a federally-created security interest? Because the PPSAs which are currently in force in Ontario, Manitoba, Saskatchewan and the Yukon Territory do not contain a comparable exclusion, there is no judicial consideration of its meaning.

A review of the case law concerning the other exclusion is of little assistance; the existing case law does not consider the extent of the exclusion of statutory liens. In National Bank of Canada v. McArthur, ${ }^{165}$ both counsel conceded that the exclusion in the Ontario PPSA meant that the registration and priority provisions were not relevant in determining the priorities between a PPSA security interest and a statutory lien. The Saskatchewan Court of Appeal, in Dube v. Bank of Montreal, ${ }^{166}$ noted that the PPSA priority rules do not apply in a contest between a PPSA claimant and the holder of a statutory lien. Similar results were reached in Northland Bank v. Flin Flon Mines Ltd. ${ }^{167}$ and Bank of Montreal v. 414031 Ontario Ltd. ${ }^{168}$

Because section 4(b) excludes only the security agreement on which a Bank Act security interest is based, a lender who wishes protection under both regimes can register security collateral to its section 177 assignment under the PPSA. It could take a security interest in the form of, and register a financing statement in respect of, an

164. (1990), 65 D.L.R. (4th) 361.

165. Supra, note 117.

166. (1986), 7 P.P.S.A.C. 223 at 227.

167. Supra, note 69 .

168. (1983), 248, 45 C.B.R. (N.S.) 77 (Ont. D.C.). 
instrument identical to the Schedule IX form of assignment, as could any secured creditor. On this basis, it seems ridiculous to suggest that the PPSA exclusion merely means that a bank must use a separate underlying security agreement to gain protection under the PPSA, especially since the PPSA is a notice, rather than a documentregistration, system. On this basis, the better view is that section 4(b) means only that a bank is not obligated to register its section 177 assignment.

This interpretation does not mean that the exclusion is only to assert the rule of federal paramountcy; it may be relevant to determining a bank's obligations under section 177(8). In order for a bank to take advantage of the priorities accorded to it in subsection (7), it must register on file the security instrument or notice in respect of its rights "in the proper land registry or land titles office or office in which are recorded the rights, licences or permits referred to in this section'. It is arguable that the rights referred to in section 177 include severed hydrocarbons and equipment and the office in which interests in severed hydrocarbons and equipment, which are not fixtures, would be registered is the PPSA Registry. The effect of section 4(b) is therefore to limit where a bank must register section 177 security; in Alberta, registration at Land Titles or at Energy, Mines and Minerals is all that is required.

A second concern of the extent of the section 4(b) exclusion is whether section 177 security can be defeated by unperfected PPSA security interests. Pursuant to section $177(7)$, a holder of section 177 security has priority over subsequently acquired rights and over certain prior rights (mechanics' liens and unpaid vendor's claims). It does not specifically require that the holder of the prior security interest have protected its interest as referred by the provincial law governing it. The result of this is that a bank could search the personal property security registry before making advances and taking section 177 security and not find any security interest claims, yet have its security defeated by an interest which was not perfected in accordance with the provincial law which governs it.

This issue has arisen in the context of section 178 security and the pre-PPSA regimes which rendered void unregistered security interests. While case law has consistently held that the holder of section 178 security steps into the shoes of the grantor, acquiring whatever rights and obligations the grantor's interest was subject to (see Royal Bank of Canada v. Hodges ${ }^{109} ;$ Re Wm. A. March Co. Ltd.; ${ }^{170}$ and Bank of Montreal v. Guaranty Silk Dyeing and Finishing Company Limited $\left.{ }^{171}\right)$, there is also a strong argument that a holder of section 178 security can rely on third party rights granted by the law governing the competing security interest. Thus, if a chattel mortgagee or conditional sales vendor failed to register its interest and the governing law invalidated unregistered interests as against third parties without notice, the bank would not be subject to the unregistered interest (see Leoville Savings and Credit Union Limited v. Campagna; ${ }^{172}$ Mutchenbacker v. Dominion Bank; ${ }^{173}$ Grouse Mountain Resorts Ltd. v. Bank of Montreal ${ }^{174}$; and Re J D Dudar \& Sons ${ }^{175}$ ).

169. [1929] 3 W.W.R. 605 (B.C.C.A.).

170. (1930), 1 C.B.R. 463 (Que. Sup. Ct.).

171. (1935), 16 C.B.R. 363 (Ont. C.A.).

172. (1970), 75 W.W.R. 661 (Sask. Q.B.).

173. (1911), 18 W.L.R. 19, (B.C.S.C.).

174. (1960), 25 D.L.R. (2d) 371 (B.C.S.C.).

175. (1982), 43 C.B.R. 61 (Alta. Q.B.). 
The scheme of the PPSA is very different, however, from the previous personal property security regime. Instead of invalidating unperfected security interests, it subordinates them to certain persons. In Rogerson Lumber Co. Ltd. v. Four Seasons Chalet Ltd., 176 the holder of section 178 security argued that an unperfected conditional sales contract was subordinated to its security pursuant to section 22(1)(a)(i) of the Ontario PPSA, which protected persons "entitled to priority under this or any other Act". However, because "Act" was defined in the provincial Interpretation $A c t^{177}$ as meaning a provincial enactment, this argument failed.

A holder of Bank Act security could argue that it obtains protection under section 20(1)(c) of the Alberta Act. This section subordinates a security interest in personal property to the interest of a transferee who:

(i) acquires the interest under a transaction that is not a security agreement,

(ii) gives value, and

(iii) acquires the interest without knowledge of the security interest and before the security interest is perfected.

The bank will have to establish that the transaction under which it acquired its interest is not a security agreement. The PPSA defines "security agreement" as "an agreement that creates or provides for a security interest, and, if the context permits, includes a writing that evidences a security agreement" (section 1(1)(pp)). Section 177 security falls within the definition of "security interest", absent the section 4(b) exclusion. Unless a bank can establish that section 177 security is a statutory security interest and is not created by an agreement, a bank may be outside of the protection of the Act. This result cannot have been intended. If the section 4(b) exclusion means that a bank cannot perfect its section 177 security under the PPSA so that it can defeat prior unperfected claims and it cannot obtain the protection accorded to third party purchasers without notice under section $20(1)$ (c) then the exclusion is extremely prejudicial to banks who take Bank Act security.

\section{PRIORITIES ISSUES}

Conflict between the priorities schemes of section 177 of the Bank Act and the PPSA are inevitable. Section $177(7)$ grants to a bank priority over all rights subsequently acquired in the charged property and over the pre-existing claims of mechanics' lien holders and unpaid vendors of equipment and casing, but not over a lien of an unpaid vendor of which the bank had knowledge when it acquired its interest. Cuming and Wood suggest that the exception contained in section 178(2) for unpaid vendor's liens of which the bank had knowledge does not include purchase-money security interests because purchase-money security are not liens. ${ }^{178}$

Both section 177(7) and section 179(1) give Bank Act security priority over claims of unpaid vendors. It is only when the unpaid vendor has a lien and the bank knows of the lien when it acquires its security interest that the lien defeats the Bank Act security. However, section 177 security defeats a prior claim by an unpaid vendor of equipment or casing. There is no reference to a lien in this part of subsection (7). Since a purchase-money security interest is a claim by an unpaid vendor and the Bank

176. (1980), 1 P.P.S.A.C. 160 (C.A.).

177. R.S.A. 1980 , c. $1-7$, s.25(1)(a).

178. R. Cuming and R. Wood, "Compatibility of Federal and Provincial Personal Property Security Law” (1985) 65 Can. Bar. Rev. 267 at 274. 
Act subordinates it to section 177 security, and the PPSA accords purchase-money security interests special priority over prior security interests, priority disputes are inevitable. For example, a purchase-money security interest in equipment has priority over a general security interest pursuant to section 34(2). According to section 177(7), however, section 177 security has priority over the prior unpaid vendor's claim (the purchase-money security interest), but not the prior general security interest.

This section of the paper will review cases considering the interaction between the two schemes and will address three priorities issues:

1. how can priority disputes between the PPSA and the Bank Act be resolved;

2. the effect of banks taking consecutive Bank Act and PPSA security; and

3. the effect of banks taking contemporaneous Bank Act and PPSA security.

1. Conflict between the Bank Act and the PPSA

A number of approaches to reconciling provincial personal property security law and federal security interests have emerged.

Early cases applied the doctrine of federal paramountcy to negate the application of provincial property law. In the case of Landry Pulpwood Co. Ltd. v. Banque Nationale, ${ }^{179}$ Mignault J. stated "there is no doubt, however, that we must look solely to the Bank Act to determine the effect of a lien acquired by a bank by virtue of section 88', recognizing Parliament's exclusive jurisdiction to legislate in respect of banks. However, in Landry there was no competing provincial property security law under consideration.

More recently, in Rogerson Lumber Co. Ltd. v. Four Seasons Chalet Ltd. ${ }^{180}$ the Ontario Court of Appeal recognized federal paramountcy stating that "the PPSA cannot prejudicially affect the bank's interest, acquired pursuant to a federal statute" (Arnup J.A. with whom Holden J.A. concurred).

The Saskatchewan Court of Queen's Bench, in the case of Royal Bank v. Erdman, ${ }^{181}$ preferred the reading-down approach advocated by the Supreme Court of Canada in Quebec North Shore Paper Co. v. CP Ltd., ${ }^{182}$ whereby provincial legislation of general application is construed so as not to apply to enterprises governed by federal legislation. Sirois J. then adopted what he called a common sense approach to resolve a priorities dispute between the holder of section 178 Bank Act security and the holder of a threshers' lien. He concluded that since the bank, if it seized the crop, would have to hire someone to harvest and thresh it, it would only have the net proceeds to satisfy its own claim. He found that the conflict between the two acts did not really exist if the bank paid the lien holder. He stated "there is absolutely no conflict in operation; there is no inconsistency [sic] between them provided that each party recognizes and respects the rights of the other and keeps them in their proper perspective." 183 By this approach, he gives effect to the provincial statute over the federal statute.

179. [1928] I D.L.R. 493 (S.C.C.).

180. Supra, note 42 at 167.

181. (1985), 5 P.P.S.A.C. 102.

182. [1977] 2 S.C.R. 1054 at 1065.

183. Supra, note 181 at 107. 
The Saskatchewan Court of Appeal applied the "first to create" theory in The Bank of Montreal v. Pulsar Ventures Inc. (1987), ${ }^{184}$ on the basis that, as between equitable charges, priority is accorded to the holder of the agreement which was executed first. Because the bank's security was granted first, he found that it attached to the inventory before Pulsar's security interest.

The rationale for the "first to create" approach, which is not discussed in the case, is the application of the common law principle of nemo dat quod non habet (that one cannot transfer better title than he possesses). Once the debtor grants a charge to the first security holder in certain collateral, all that remains to be charged by subsequent collateral is the debtor's remaining interest.

The application of the "first to create" principle is interesting. The bank had taken section 178 security and registered a notice of intention under the Bank Act and registered a financing statement under the PPSA. Perfection of the bank security interest occurred before Pulsar, the competing creditor, perfected its interest, so the case could have been resolved on the basis of order of perfection. However, the Court of Appeal stated that registration of a section 178 security interest under the PPSA is not an election by the bank to abandon its rights under the Bank Act and to submit to the PPSA exclusively.

The Court adopted a federal paramountcy approach, stating: ${ }^{185}$

If the Bank Act provides directly or by implication a priority rule then that provision will govern notwithstanding that it is in conflict with a provincial scheme of priorities. This rule is based on the primacy of federal law.

In Bank of Nova Scotia v. International Harvester Credit Corporation of Canada $L t d .,{ }^{186}$ a bank perfected a section 178 security interest under the PPSA and filed a notice of intention to give section 178 security. The Ontario Supreme Court found that the PPSA was not so inconsistent with the Bank Act that federal paramountcy would operate and permitted the bank to pursue PPSA remedies rather than Bank Act remedies.

The Supreme Court of Canada has recently increased the scope of the federal paramountcy doctrine. In Bank of Montreal v. Hall, ${ }^{187}$ a bank which held section 178 security sought to enforce its security by selling the charged property. The Saskatchewan Limitation of Civil Rights Act ${ }^{188}$ imposed court supervision on realizations of secured debts, thereby precluding immediate sales. While the bank could, by complying with the stricter provincial legislation, comply with both enactments, the Supreme Court found this to be "an actual conflict in operation" between the two acts. Because of the doctrine of federal paramountcy, the Bank Act was operative: 189

I am firmly of the view that the security interest and realization procedure must, in essence, be viewed as a single whole in that both components of the legislation are fully integral to Parliament's legislative purpose in creating this form of financing. In other words, a section 178 security interest would no longer be cognizable as such the moment provincial legislation might operate to superadd conditions governing realization over and above those found within the confines of the Bank Act. To allow this would be to set at naught the very purpose behind the creation of the section 178 security interest.

184. (1987), 7 P.P.S.A.C. 258.

185. Ibid., at p. 264.

186. (1987), 7 P.P.S.A.C. 1.

187. Supra, note 164 .

188. R.S.S. 1978 , c. L-16.

189. Supra, note 164 at 384. 
Surely, this reasoning is equally applicable to the conflict between the provincial and federal priorities schemes. The PPSA cannot operate to vary the priorities scheme which is clearly set out in section 177(7). However, where a bank chooses to register its interest under the PPSA and elects to proceed under that regime rather than under the Bank Act (as in the International Harvester ${ }^{190}$ case), there is no reason why that election should not be effective.

\section{Consecutive Security}

Where a bank takes section 177 security and, subsequently, obtains a floating charge debenture or a general security agreement, the section 177 security will be the superior security on the basis of the nemo dat quod non habet principle. Once the debtor grants a section 177 security interest in assets, a subsequent security can only attach to whatever rights the debtor has left in the collateral. The same is true where a bank takes PPSA first and then follows it with section 177 security. However, in Birch Hills Credit Union Ltd. v. Canadian Imperial Bank of Commerce, ${ }^{191}$ a subsequent general security agreement was found to have been intended to be the primary security because it covered more collateral than the earlier section 178 security. However, we believe that the correct approach would be that for the collateral covered by the section 178 security, the section 178 security operates. The PPSA security interest, however, is the primary security for the additional collateral, and can attach to whatever rights the debtor had remaining in the original collateral.

\section{Contemporaneous Security}

When banks take section 177 security in the same transaction as PPSA security, two approaches can be applied. First, as in the International Harvester ${ }^{192}$ case, the bank can elect which security to enforce. The problem with this approach is that it does not give effect to the nemo dat quod non habet principle. The two security interests are not, in fact, given simultaneously. One must have preceded the other and the first one will have encompassed greater rights. A second problem is that it will be very difficult to ascertain which was executed first.

The second approach is to apply the quantum theory outlined by Cuming and Wood ${ }^{193}$ and which has been applied in Birch Hills Credit Union Ltd. v. Canadian Imperial Bank of Commerce ${ }^{194}$ and Bank of Montreal v. Pulsar Ventures Inc. ${ }^{195}$ According to this theory, different security interests attach to a different quantum of rights, and the system of law governing the greater rights (the "primary security") is to govern both security interests. To determine which is the primary security, Cuming and Wood suggest looking to the order in which the security agreements were executed. However, if one knows the order in which the interests were created, then on the nemo dat quod non habet principle, the first in time covers the greater

190. Supra, note 186.

191. (1987), 7 P.P.S.A.C. 250.

192. Supra, note 186.

193. Supra, note 178.

194. Supra, note 191.

195. Supra, note 184. 
interest. If the sequence of documents cannot be determined, Cuming and Wood state that some presumption must be applied and that since Bank Act security is unique to banks, it should be presumed to be the primary security. (Note that in the Birch Hills Credit Union case, this presumption was rejected because the general security agreement covered more collateral).

The quantum theory provides a practical resolution to the problem of determining which security interest is dominant. However, on a conceptual basis, we see no reason why a bank, as the holder of all of the rights granted in the security, should be prevented from electing its remedies thereunder.

\section{NOTICE TO ACCOUNT DEBTORS REQUIRED UNDER THE PPSA?}

\section{A. GENERAL AND SPECIFIC ASSIGNMENTS OF REVENUES}

Assignments of revenues due from a debtor under specified contracts are often taken as security in oil and gas financings. These security interests are reflective of the oil and gas business where significant long-term gas sales contracts are prominent. Gas contracts are a long-term source of revenue for many producers. Although these arrangements are less common, some producers sell other production under long-term contracts, or farm out properties and retain significant gross overriding royalty interests, net profit interests or other revenue interests. These revenue interests are generally not interests in land; however, they again constitute long-term revenue interests. Where revenue interests of this nature constitute a significant asset of the company, they are typically secured by absolute assignments of revenues from specifically identified contracts. There is an interpretation of the Business Corporation $A c t^{196}$ which would favour the registration of absolute specific assignments of revenue securing debentures as defined in that Act. Although the practice is very inconsistently followed, some practitioners register such security interests at the Corporate Registry.

Registration of assignments of revenues under the Business Corporations $A C t^{197}$ or the Assignment of Book Debts $A c t^{198}$ operates to make the security interests effective against certain third parties. Failure to register when required means that the secured lender's interest would be void against certain third parties, including creditors. These acts, however, do not constitute a comprehensive code indicating how priority is attained; they merely preserve rights. Issues of priority remain to be determined in accordance with the old common law rules.

As discussed above, the PPSA is clearly applicable to general and specific assignments of revenues where such assignments secure obligations. The Act does not draw any distinction between specific and general assignments of revenues. In addition, the Act sets forth the method of perfecting a security interest in such collateral and the priority rules.

196. Supra, note 8.

197. Ibid.

198. Supra, note 7. 


\section{B. SHOULD ACCOUNT DEBTORS BE NOTIFIED OF GENERAL OR SPECIFIC ASSIGNMENTS AFTER THE PPSA BECOMES EFFECTIVE?}

The PPSA sets out the rules for perfecting a security interest and for gaining priority with respect to the subject collateral but does not resolve the issue of whether account debtors under long-term contracts should be notified of an assignment after the Act becomes effective. Borrowers generally oppose the notification system as they fear that it may be construed by the outside world as an indication of financial instability. Notwithstanding this predictable reaction by borrowers, notifications are routinely served on account debtors in the case of long-term gas sales contracts. As part of the notification process, these account debtors are advised by the secured party to continue paying the borrower until otherwise directed by the secured party. Where the security interest consists of a general assignment of debts, notice is typically not served until default or realization.

Clearly, with respect to general assignments of debts, the notification of account debtors will be as impracticable after the Act as before. The list of account debtors constantly changes and the size of the receivables fluctuates. The real issue, therefore, is whether payors under long-term contracts, such as gas purchasers, require notification after the Act.

Under the current laws, the provision of notice to buyers serves various purposes:

(a) According to the old common law rule in Dearle v. Hall, ${ }^{199}$ notice operates to change the cestui que trust or beneficiary of the proceeds. Once it has notified an account debtor, the second party, unless it knows of a prior interest and with some other limited exceptions, has priority to the proceeds. The account debtor in law has an obligation to deliver the proceeds to or as directed by the secured party. If the account debtor pays anyone other than the secured party, it does so at its peril. Accordingly, a Dearle v. Hall notice effects a significant legal result as it sets the priority of the secured party to the account. As the Act now lays down its own priority rules, the Dearle v. Hall notice should no longer be required for that purpose. Judicial support for the foregoing is recognized in Royal Bank of Canada v. Inmont Canada Ltd. ${ }^{200}$

(b) The notice to account debtors also has the effect of directing the flow of funds. In most cases, lenders advise the account debtor of the assignment but request that the cash flow stream not be interrupted until further notification by the lender. As a practical matter, the lender has put the account debtor on notice of its interest. If the account debtor subsequently receives a further direction by the assignor directing the account debtor to pay a third party, the account debtor will typically seek the advice and consent of the assignee prior to complying with the direction. Thus, the notice makes the account debtor the watch dog of the assignee. If the lender requires that type of monitoring or specifically requires that the funds be directed in a particular manner, notice remains necessary. 
(c) Section 21 of the Judicature Act ${ }^{201}$ of Alberta applies to assignments of debts and other legal choses in action. According to that Act, if express notice in writing of the assignment has been given to the account debtor, the absolute assignment is effectual in law to pass and transfer the legal right to the debt from the date of the notice; all legal and other remedies for the debt are transferred to the assignee and the assignee has power to give a good discharge for the debt. Although the case law is not entirely consistent, it is generally thought that the Judicature Act effected a procedural change in the law such that the person serving the notice on an account debtor has the legal right to the debt and can sue to recover the same in its own name (see Dell v. Saunders, ${ }^{202}$ and Todd v. Phoenix ${ }^{203}$ ). Prior to this Act, action for recovery had to be initiated by the assignor and was subject to the delays, tactics and cross-claims of the assignor. Although for the most part the Judicature Act only confers a technical advantage, in practical terms the advantages of that Act can be real as there is value in having control of an action against the account debtor.

The Judicature Act is not affected by the PPSA. It may be that the interplay between the Judicature Act and the PPSA will be such that the notifying assignee will have the right to receive the revenues from the account debtor but the person who perfects his security under the PPSA may have priority to that same revenue (see discussion of section 31 of the PPSA below in (c)). As a practical matter, this may mean that the Judicature Act assignee will be compelled to pass over any funds received from the account debtor to the perfected PPSA assignee. Again, although it is hard to predict the degree to which these arrangements will prove difficult in any given case, it is possible that where notice is not served, the assignee may find that it has lost some degree of control at the enforcement stage and may have to engage a third party in the enforcement of its interests.

(d) The service of notice also has the effect of ending the right of the account debtor to set off amounts owing to it by the assignor against amounts owing by that account debtor. Since, after the service of notice, the debt is no longer payable to the assignor, the account debtor, with some limited exceptions, is no longer permitted to set off, from the amount owing under the assigned account, any amounts that it is owed by the assignor. Section 4(a) of the Act specifies that the Act does not apply to a charge or other interest governed by an Act or rule of law in force in Alberta. The right of set-off is sometimes classified as arising by rule of law. As well, section 41 of the Act, which applies directly to the rights of assignees, states that an assignee is subject to any other defence or claim of the account debtor against the assignor that accrues before the account debtor receives notice of the assignment. This provision reiterates the common law, that notice remains significant in reducing the ability of the debtor to cross claim and set off amounts.

201. R.S.A. 1980 c. J-1.

202. (1914), 6 W.W.R. 657 (B.C.C.A.).

203. (1894), 3 B.C.R. 302. 


\section{SPECIAL PROVISIONS OF THE PPSA DEALING WITH ACCOUNT RECEIVABLES}

Section 41 of the PPSA applies directly to the rights of assignees of accounts, providing that an assignee is subject to the terms of the contract between the account debtor and the assignor and to any defence or claim arising out of the contract.

According to section 7 of the Act, the validity and perfection of a security interest in an intangible (i.e. a contract or account receivable) is governed by the law of the jurisdiction where the debtor is located when the security interest attaches. However, subsection (6) states that the validity, perfection and effect of perfection or nonperfection of a security interest in an account resulting from the sale of the minerals at the wellhead is governed by the law of the jurisdiction in which the wellhead is located. This convenient jurisdiction rule is complicated and may be nullified by the reference to "sale of minerals at the wellhead". Oil may sometimes be sold at the wellhead; however, it is unlikely that we will encounter many instances when gas would be sold at the wellhead. Gas is typically sold at the plant gate or immediately inside or outside of the Alberta border.

Section 10 of the Act pertains to the enforceability of a security interest and states that a security interest is unenforceable unless the collateral is in the possession of the secured party or the security agreement contains a description of the collateral by item or kind. Subsection 10(5) states that the security interest in proceeds is not unenforceable against a third party by reason only that the security agreement does not contain a description of the proceeds.

Section 31 provides that a holder of money has priority over any security interest perfected by registration or temporarily perfected under subsection $28(3)$ if the holder acquired the money without knowledge that it was subject to a security interest or is a holder for value whether or not it has knowledge that the money was subject to a security interest. This means that a person who provides consideration and who actually succeeds in getting possession of money from an account debtor has priority to that money. Under the previous law, a person with notice of a prior claim to money was subject to the priority of the prior claimant. Section 31 raises an interesting hypothetical problem. Section 21 of the Judicature $A c t^{204}$ gives the notifying assignee the legal entitlement to the assigned debt or the right to receive it. How does this provision interface with section 31(1)? Does it mean that an assignee who gives notice under the Judicature Act and who actually receives payment has priority to those proceeds? The uncertainty which the section imports to the assignee strengthens the arguments in favour of notifying account debtors where a major debt forms part of the assets in a security package.

204. Supra, note 201. 